\title{
A OROGÊNESE BRASILIANA NO SEGMENTO CENTRAL DA FAIXA RIBEIRA, BRASIL
}

\author{
MONICA HEILBRON*, CLÁUDIO DE MORISSON VALERIANO*, CLÁUDIA SAYÃO VALLADARES* \& \\ NUNO MACHADO**
}

\begin{abstract}
THE BRASILIANO OROGENY AT THE CENTRAL SEGMENT OF RIBEIRA BELT, BRAZIL The structure of the central segment of the Ribeira belt is defined by three large thrust sheets (Lower, Intermediate and Upper) which override the autochthonous domain, towards the southern portion of the São Francisco Craton. Four lithotectonic associations are individualized within the domains: basement rocks (pré-1,8 Ga rocks); orthogneisses of unknown age; Post-1,8 Ga metasedimentary cover and Brasiliano granitoid rocks. Continental tholeiitic deformed dykes and disrupted lenses within the cover indicate extensional periods. Investigation of the tectono-metamorphic and magmatic aspects, associated with new $\mathrm{U} / \mathrm{Pb}$ geocronological data support the subdivision of Brasiliano Orogeny within three main tectonic periods: a) the syn-collisional period $(590-563 \mathrm{Ma})$ is represented by the main deformation $\left(\mathrm{D}_{1+2}\right)$, coeval with the MI metamorphic stage and $\gamma 1-\gamma 3$ granitoid rocks. Crustal shortening took place initially through ductile thrusts and tight recumbent folds. The late stage of this collisional event is characterized by oblique convergence, with pervasive deformation throughout the belt. MI had its thermal peak during $\mathrm{D}_{2}$, and is characterised by intermediate to high pressures. The spatial distribution of the metamorphic zones defines an inverted gradient. Deformed I and S type granitoid rocks occur during this period, b) the post-collisional period (535-520 Ma) is characterized by $\mathrm{D}_{3}$ deformation, coeval with $\mathrm{M}_{2}$ metamorphic stage. During DS phase, the oblique convergence continued, but was accomodated by late to post-metamorphic peak strike slip ductile shear zones. Between these shear zones, shortening was achieved by steep folding of $S_{2}$ foliation. The Ma stage with lower pressure regime is associated with intense melting of the basement and the cover, resulting in the generation of I-type magmatism and subordinated S-type; and c) the post-tectonic period is represented by the Post-D4 $\gamma_{5}$ magmatism registered between 503 to 492 Ma. This magmatism may be related to melting of crustal rocks associated with mantelic contribution related with high temperature conditions and uplift just after the Brasiliano Orogeny.
\end{abstract}

Keywords: Panafrican, mobile belt, Neoproterozoic/Cambrian, tectono-metamorphic evolution, Paleoproterozoic basement

RESUMO A estruturação geral do segmento central da Faixa Ribeira foi compartimentada em três domínios tectônicos alóctones (Inferior, Médio e Superior), imbricados de SE para NW em direção ao Domínio Autóctone que bordeja o Craton do São Francisco. Quatro principais unidades lito-tectônicas foram individualizadas em todos os compartimentos tectônicos: embasamento pré-1,8 Ga; ortognaisses com posicionamento temporal não definido; cobertura metassedimentar pós-1,8 Ga; e rochas granitóides relacionadas à Orogênese Brasiliana. A análise da evolução estrutural/metamórfica/magmática nos diferentes compartimentos, combinada com a obtenção de novos dados geocronológicos U/Pb, permitiu a subdivisão da Orogênese Brasiliana em três principais períodos tectônicos: sin-colisional (590-563 Ma); pós-colisional (535-520 Ma) e pós-tectônico (503-492 Ma). O período sin-colisional é caracterizado pela deformação principal $\left(\mathrm{D}_{1+2}\right)$, responsável pelo empilhamento tectônico, inicialmente representada por dobras recumbentes e empurrões dúcteis com vergência para a área cratônica, que posteriormente passa a registrar uma importante componente de movimentaçãoo oblíqua (inversa e dextral). Este período está associado à etapa metamórfica $\mathrm{M}_{1}$ com regime de pressão média a alta e zoneamento inverso, e a granitóides deformados do tipo I e $\mathrm{S}(\gamma 1-\gamma 3)$. O período pós-colisional é representado pela fase de deformação tardia $\left(\mathrm{D}_{3}\right)$, que resolveu o encurtamento através do redobramento íngreme da foliação pré-existente e da implantação de zonas de cisalhamento com componente direcional dextral. A este período está associado à etapa metamórfica Ma, com regime de pressão mais baixa, responsável pela intensa fusão parcial da cobertura e do embasamento na porção mais interna da faixa, resultando na geração de diversos corpos granitóides, mais abundantes próximo à região costeira do estado do Rio de Janeiro. $\mathrm{O}$ período pós-tectônico representa a transição para o regime distensional predominante no Fanerozóico, com a geração de corpos granitóides isotrópicos, comumente associados a rochas básicas.

Palavras-chaves: Panafricano, faixa móvel, Neoproterozóico/Cambriano, evolução tectono-metamórfica, embasamento paleoproterozóico

INTRODUÇÃO A definição de compartimentos ou domínios tectônicos, sua litoestratigrafia e evolução tectonometamórfica comparativa constituem modernas formas de abordagem em faixas móveis. No caso das faixas precambrianas brasileiras, nas quais é ainda incipiente o acervo geocronológico, esta abordagem torna-se especialmente importante. De forma geral, os problemas de correlação aumentam para o interior das faixas, em virtude do alto grau metamórfico, da migmatização, da abundância de rochas granitóides intrusivas, além da deformação mais intensa. Como no caso da zona interna do Segmento Central da Faixa Ribeira (FR), aqui abordada, estes aspectos dificultam a discriminação da cobertura, do embasamento retrabalhado e dos granitóides deformados.
Buscando contribuir para a evolução brasiliana da FR, este trabalho apresenta uma nova proposta de organização tectônica de seu Segmento Central (Fig. 1), bem como a cartografia da cobertura metassedimentar, do embasamento retrabalhado e dos granitóides intrusivos nos seus diferentes compartimentos. Com base em novos dados geocronológicos pelo método $\mathrm{U} / \mathrm{Pb}$ e na relação temporal entre o magmatismo, $\mathrm{o}$ metamorfismo e a deformação, é proposto também um quadro evolutivo da Orogênese Brasiliana, posicionando os processos geológicos nos seus estágios pré, sin e pós-colisional e pós-tectônico.

\footnotetext{
* Departamento de Geologia Regional e Geotectônica, Faculdade de Geologia, Universidade do Estado do Rio de Janeiro (UERJ), Rua São Francisco Xavier 524, sala A 4024. Maracanã, Rio de Janeiro, RJ, cep 20550-900, Brasil, tel 021- 5877102 fax 021- 2546675

** Geotop- Departement de Sciences de Ia Terre. Université du Québec à Montreal. Qué.H3C 3P8, Canadá
} 
CONTEXTO GEOTECTÔNICO A FR (Cordani et al. 1973; Almeida et al. 1973) compreende um complexo cinturão de dobramentos e empurrões gerado no Neoproterozóico/Cambriano, durante a Orogênese Brasiliana, na borda sul/sudeste do Cráton do São Francisco (Barbosa 1966, Almeida 1969,1977). Para localização de sua situação geotectônica e relação com outras faixas móveis vide a Figura 1 .

Diversos modelos evolutivos já foram apresentados para a FR, no âmbito do Estado do Rio de Janeiro e regiões vizinhas em Minas Gerais e São Paulo. Dentre estes, destacam-se os trabalhos de Ebert (1968, 1984), Almeida et al (1973, 1976), Hasui et al. (1975), Hasui (1982), Cordani et al. (1988), Tassinari \& Campos Neto (1988), Ribeiro et al. (1990), Heilbron (1990, 1993, 1995), Brito Neves \& Cordani (1991), Ebert et al (1991), Campos Neto \& Figueiredo (1995), Junho (1990), Machado \& Endo (1993), Trouw et al. (1994) e Heilbron et al. (1994). Apesar das diferentes propostas de evolução, monocíclicas ou policíclicas, ensiálicas ou com a participação de crosta oceânica, é consenso entre todos estes autores que a FR representa a raiz de um orógeno colisional neoproterozóico, profundamente erodido.

Alguns autores (Hasui \& Oliveira 1984; Campos Neto 1992, entre outros) propõem a existência de uma unidade tectônica na borda cratônica, denominada Faixa Alto Rio Grande, com evolução bicíclica no Meso e Neoproterozóico, representada pelas Orogêneses Uruaçuana e Brasiliana, respectivamente. Outros autores (Ebert 1984, Trouw et al 1994) consideraram este setor corno resultante da interferência entre duas faixas moveis, Brasília e Ribeira. No presente trabalho, é proposta uma evolução monocíclica para o segmento central da FR, durante a Orogênese Brasiliana. A região correspondente à "Faixa Alto Rio Grande" é considerada equivalente à zona externa da FR (vide Figura 1), apesar de apresentar evidências metamórficas e deformacionais relativas à interferência da tectônica da Faixa Brasília (Ebert 1984; Trouw et al 1994), esta com transporte tectônico dirigido para ESE .

\section{COMPARTIMENTAÇ̃̃O TECTÔNICA DO SEG-} MENTO CENTRAL DA FR Base de dados utilizada $\mathrm{O}$ mapeamento geológico detalhado, realizado na escala de 1:50.000 e integrado para mapas regionais ao milionésimo, foi combinado com investigações da evolução tectono-metamórfico-magmática, somadas a dados geoquímicos e geocronológicos obtidos na seção transversal Bom Jardim de Minas (MG)- Rio de Janeiro (RJ). Tal acervo de dados permitiu a proposição de uma subdivisão tectônica

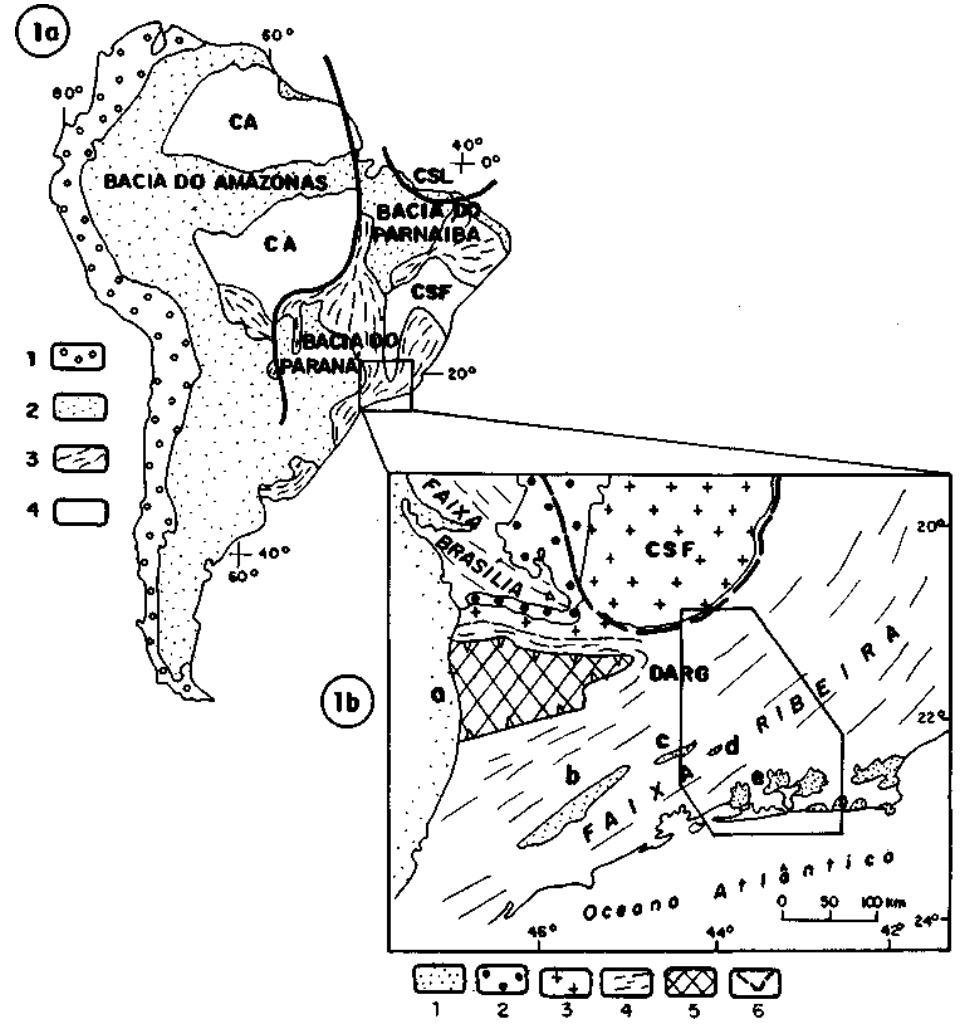

Figura l - Localização Geotectônica. (a) - Situação da Faixa Ribeira no contexto da Plataforma Sul-Americana, simplificado de Brito Neves \& Cordani (1991). Simbologia: 1-Faixas Móveis Meso-Cenozóicas; 2- Coberturas de plataforma fanerozóicas; 3- Faixas Móveis Sin-Brasilianas; 4- Crátons Sin-Brasilianos. (b) -Localização da transversal abordada no contexto do sudeste brasileiro, elaborado a partir de Hasui \& Oliveira (1984), Campos Neto (1992), Valeriano et al (1993) e Trouw et al (1994). Simbologia: l- Bacias F anerozóicas: a- Paraná, b-Taubaté, c-Resende, d-Volta Redonda, e-Rift da Guanabara; 2- Grupo Bambui; 3- Embasamento pré-1,8 Ga no Cráton do São Francisco; 4- Faixas Brasília e Ribeira, DARG- Domínio Alto Rio Grande; 5-Nappe Guaxupé; 6-Limite cratônico

Figure 1 - Tectonic Context: (a) Relationship of the Ribeira belt within the South-American platform, simplified from Brito Neves \& Cordani (1991). Legend: 1 - Mesozoic/Cenozoic mobile belts; 2-Phanerozoic platforma cover; 3- Brasiliano mobile belts; 4- Syn-Brasiliano cratons. (b) Tectonic context of the southeastern portion of Brazil, adapted from Hasui \& Oliveira (1984), Campos Neto (1992), Valeriano et al. (1993) and Trouw et al. (1994). Legend: 1- Phanerozoic basins: a- Paraná, b-Taubaté, c- Resende, d- Volta redonda, e- Guanabara; 2- Bambuí group; 3- Pré-1.8 Ga basement of the São Francisco craton; 4- Brasília and Ribeira belts, DARG- Alto Rio Grande Domain; 5- Guaxupé nappe; 6- Limit of São Francisco craton. 
preliminar(Heilbron 1990, 1993, Heilbron et al 1993a). Esta proposta original de compartimentação tem sido testada em outras duas seções transversais (Aiuruoca-Mangaratiba e Santa Rita do Ibitipoca-Valença, ao longo de dez anos de pesquisa (Heilbron et al. 1991, Almeida et al. 1993, Dios et al. 1993, Heilbron 1990, 1993, Heilbron et al. 1992, 1993a, 1993b, 1994b, Duarte et al 1994).

Foram também integrados os resultados obtidos por Trouw et al. (1986), Ribeiro et al. (1990) e Pacciulllo et al (1993), para a região da folha Barbacena (escala 1 :250.000), referentes à zona externa da faixa (Fig. 2), bem como os dados da borda sul do Cráton do São Francisco, apresentados por Teixeira et al (1987) e Teixeira \& Figueiredo (1991). Para completar o quadro regional, foram ainda compilados os levantamentos geológicos de Helmbold et al (1965), Penha et al (1980), Sad et al. (1980), Reis et al (1982), Ferrari et al. (1982), Pires et al (1982), Valeriano \& Magalhães (1984), Machado (1984), Valeriano (1985), Silva \& Silva (1987), Gonçalves (1987), Bittar (1990), Silva (1991), Silva et al (1987, 1991) Nummer (1992) e Nogueira \& Trouw (1993).

Proposta de Compartimentação Tectônica para o Segmento Central da FR Com base nos dados disponíveis, foi elaborada uma proposta de compartimentação tectônica regional, na escala ao milionésimo, para o Segmento Central da FR. Esta proposta subdivide o segmento investigado em quatro domínios tectônicos imbricados em direção à área cratônica (Fig. 3), conforme o esquema abaixo:

\begin{tabular}{|c|c|c|}
\hline \multirow{3}{*}{ N/NW } & ZONA EXTERNA & Domínio Autoctone \\
\cline { 2 - 3 } & ZONA INTERNA & Domínio Aloctone Inferior \\
\cline { 3 - 3 } S/SE & & Domínio Alóctone Médio \\
\cline { 3 - 3 } & & Domínio Aloctone Superior \\
\hline
\end{tabular}

Estas denominações, de âmbito mais regional, correspondem aos domínios Paraíba do Sul (Superior), Juiz de Fora (Médio), Andrelândia (Inferior) e Autóctone, adotados por Heilbron (1990, 1993), para a seção situada entre as cidades de Bom Jardim de Minas (MG) e Barra do Piraí (RJ), e por Heilbron et al (1991, 1994), para a seção até o litoral.

Os domínios tectônicos aqui propostos são considerados como segmentos crustais com constituição litológica própria e característica evolução tectono-metamórfica durante a Orogênese Brasiliana. São separados por importantes descontinuidades estruturais, reconhecidas como zonas de cisalhamento dúcteis, de baixo a alto ângulo, com componentes de movimentação inversa e dextral. A componente de movimentação vertical está presente em várias destas zonas, definindo uma movimentação geral oblíqua. Esta compartimentação tectônica regional, estabelecida no início da convergência brasiliana, foi modificada pelas fases de deformação tardias (Fig. 3), através de megadobramento em escala regional, destacando-se aí a Megassinforma do Rio Paraíba do Sul (Heilbron et al 1991) e a Megantiforma do Rio de Janeiro, ou através de zonas de cisalhamento verticais importantes como a do Rio Paraíba do Sul (Campanha \& Ferrari 1984, Chrispim \& Tupinambá 1989, Dayan \& Keller 1989).

Buscando simplificar o confuso quadro de nomenclaturas já adotadas para este setor da FR, adotou-se uma subdivisão litotectônica simplificada, nas seguintes unidades: a) embasamento pré-1,8 Ga (rochas formadas e/ou retrabalhadas no Evento Transamazônico);

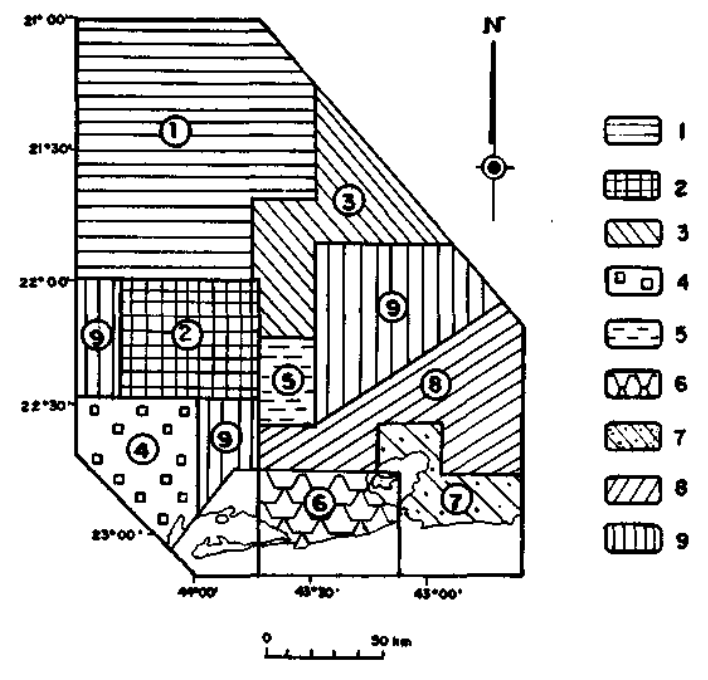

Figura 2 - Base de dados utilizada para elaboração do mapa tectônico na escala ao milionésimo. Simbologia: 1- Trouw et al (1986), Ribeiro et al (1990) (1:250.000); Valeriano (1985), Bittar (1990), Gonçalves (1987), Nummer (1992) e Silva (1990) (1:25.000 e 1:50.000); 2- Heilbron (1993) (1:100.000); 3- Heilbron et al (1994), Nogueira (1994), Duarte et al. (1994) e Nummer (1992) (1:25.000 e 1:50.000); 4- Heilbron et al (1991), Almeida et al (1993) e Dios (1993) (1:50.000 e 1:100.000); 6- Helmbold et al. (1965), Pires et ai (1992), Heilbron et al (1993b), Valeriano \& Magalhães (1984), Silva \& Silva (1987), Silva et al (1991) (1:10.000 e 1:50.000); 7- Ferrari et al (1982) (1:50.000); 8- Reis et al (1982), Penha et al. (1979,1980), Grossi Sad et al (1980) (1: 50.000); 9- Dados inéditos do Departamento de Geologia Regional e Geotectônica-FGEL/UERJ Figure 2 - Geological data base for the tectonic maps of figures 3 and 4

b) ortognaisses sem determinações geocronológicas, provavelmente integrantes do conjunto do embasamento;

c) cobertura metassedimentar pós-1,8 Ga e

d) rochas granitóides geradas da Orogênese Brasiliana, classificadas segundo sua relação temporal com as diversas fases geométricas de deformação.

O padrão de distribuição regional destas unidades litotectônicas é apresentado na escala ao milionésimo (Fig. 4). Maiores detalhes sobre a constituição, nomenclatura e correlação estratigráfica das unidades litológicas em cada domínio tectônico podem ser encontradas em Heilbron (1995). Uma síntese da nomenclatura litoestratigráfica adotada é apresentada da tabela 1 .

\section{Apresentação dos Domínios Tectônicos}

DO- MÍNIO AUTÓCTONE (DA) Bordeja o limite sul/ sudeste do Cráton do São Francisco e é constituído por associações litológicas onde a distinção entre cobertura e embasamento é clara. Diversos pulsos de magmatismo básico associados a etapas distensionais são registrados no âmbito deste domínio (Ribeiro et al 1990). Como melhor verificado na cobertura supracrustal, apresenta nítida polaridade deformacional e metamórfica, com diminuição de intensidade em direção à área cratônica.

DOMÍNIO ALÓCTONE INFERIOR (DI) É representado por um conjunto metassedimentar intensamente deformado, de idade Meso a Neoproterozóica (Ciclo deposicional 

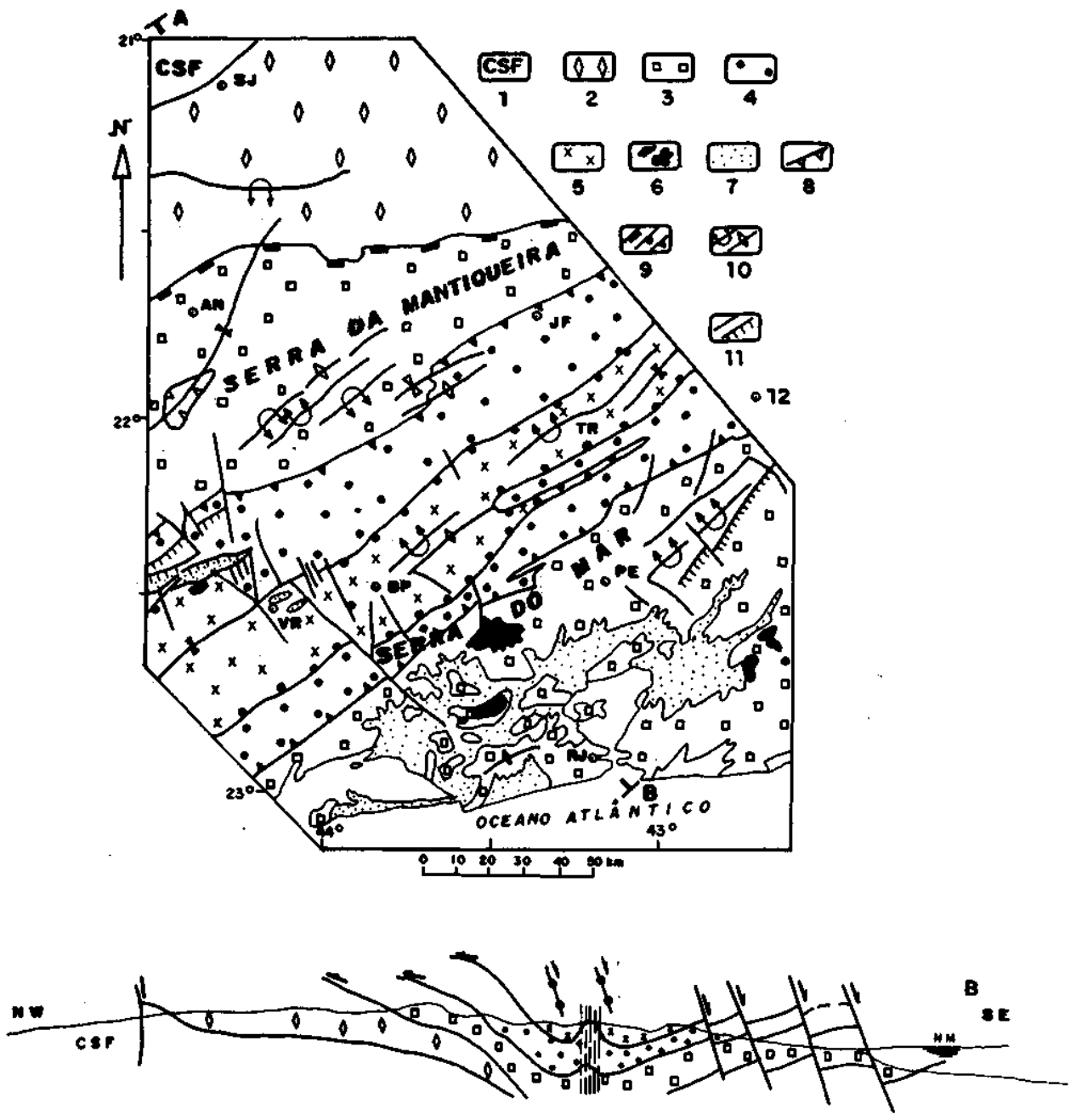

Figura 3 - Proposta de Compartimentação Tectônica do Segmento Central da Faixa Ribeira, baseada em Heilbron (1995). Simbologia: 1- Craton do São Francisco; 2-Domínio Autóctone; 3- Domínio Alóctone Inferior; 4-Domínio Alóctone Médio; 5Domínio Alóctone Superior; 6-Intrusivas Alcalinas Meso-Cenozóicas; 7- Cobertura Fanerozóica; 8-Empurrão relacionado à deformação principal; 9- Empurrões basais dos compartimentos tectônicos; 10- Traços axiais do redobramento regional; 11-Zonas de cisalhamento rapteis fanerozóicas; 12- Principais cidades- SJ/São João dei Rei, AN/Andrelândia, JF/Juiz de Fora, VRNolta Redonda, BP/Barra do Piraí, TR/Três Rios, PE/Petrópolis e RJ/Rio de Janeiro.

Figure 3 - Proposed tectonic compartmentation of the central segment of the Ribeira belt (Heilbron, 1995). Legend: 1- São Francisco craton; 2- Autochthonous domain; 3 to 5 Allochthonous domains (3- Lower, 4 - Intermediate, 5- Upper); 6- Meso/Cenozoic alkaline intrusions; 7- Phanerozoic cover; 8- Main Deformation Phase related thrusts; 9-Basal thrusts of the tectonic domains; 10- Axial traces of regional refolding structures; 11-Phanerozoic brittle shear zones; 12-Localities

Andrelândia e unidades correlatas na região da Serra do Mar e costeira do Estado do Rio de Janeiro), e por seu embasamento consolidado no Evento Transamazônico. O embasamento é composto por ortognaisses migmatíticos, com rochas granulíticas, rochas ultramáficas e anfibolitos, constituindo uma típica associação de alto grau metamórfico no Paleoproterozóico e Arqueano de diversos continentes (Condie 1989). Apesar da deformação intensa, com megadobras apertadas a isoclinais, recumbentes a inclinadas, associadas a zonas de cisalhamento, que envolvem os dois conjuntos acima mencionados, a distinção entre cobertura e embasamento pode ser estabelecida com confiança.

DOMÍNIO ALÓCTONE MÉDIO (DM) Caracteriza-se por intensa interdigitação tectônica entre dois conjuntos litológicos distintos, representados por metassedimentos pós1,8Ga do Ciclo Deposicional Andrelândia e correlates, e por ortognaisses e ortogranulitos de idade paleoproterozóica a arqueana. Este último conjunto, que vem sendo denominado de Complexo Juiz de Fora, é aqui interpretado como embasamento do primeiro (Heilbron 1993). Escamas de rochas metapelíticas, na fácies granulito, também ocorrem interdigitadas neste compartimento e, por enquanto, possuem posicionamento temporal duvidoso. As intensas deformações e imbricações tectônicas, associadas ao estudo detalhado da deformação, indicam que este compartimento representa uma importante escama tectônica em escala crustal, que parece ter acomodado e resolvido grande parte do encurtamento durante a Orogênese Brasiliana.

DOMÍNIO ALÓCTONE SUPERIOR (DS) Representa a escama tectônica superior neste segmento da FR. Apresenta deformação menos intensa, com exceção das zonas mais próximas de seu contato basal. Caracteriza-se por um conjunto supracrustal de posicionamento temporal duvidoso, conhecido como Grupo Paraíba do Sul, e por ortognaisses transama- 
Tabela 1- Quadro Sintético com a correlação entre a nomenclatura litoestratigráfica mais comumente utilizada no segmento da Faixa Ribeira abordado. * Posicionamento temporal tentativo de unidades sem confirmação geocronológica.

Table 1 - Correlation of the litho-stratigraphic nomenclatura within the tectonic domains of the central segment of the Ribeira belt.

\begin{tabular}{|l|l|l|}
\hline Domínio Tectônico & \multicolumn{1}{|c|}{ Embasamento Pré-1,8 Ga } & \multicolumn{1}{c|}{ Coberturas Pós- 1,8 Ga } \\
\hline Autóctone & Complexos Barbacena, Divinópolis, Mantiqueira & Ciclos Deposicionais Andrelândia, Carandar, Lenbeiro e Tiradentes \\
\hline Inferior & $\begin{array}{l}\text { Complexos Mantiqueira, Rio Negro }\left(^{*}\right) \text { e Região dos } \\
\text { Lagos, Série Inferior, Plagioclásio Gnaisse. }\end{array}$ & $\begin{array}{l}\text { Ciclo Deposiçional Andrelândia e correlatos (unidades Palmital, Santo } \\
\text { Eduardo, Catalunha, São Fidélis, Pão de Açúcar, Búzios, Seq. Superior) }\end{array}$ \\
\hline Central & Complexo Juiz de Fora & $\begin{array}{l}\text { Ciclo Deposional Andrelândia e correlatos (unidades Raposos, Três } \\
\text { Ithas, Itaocara) }\end{array}$ \\
\hline Superior & Suite Quirino & Grupo Paraiba do Sul (*), Itaocara, Parafba/ Desengano \\
\hline
\end{tabular}

zônicos da Suíte Quirino, além de inúmeros corpos granitóides intrusivos brasilianos.

A OROGÊNESE BRASILIANA Os efeitos tectonometamórficos e o magmatismo resultantes da Orogênese Brasiliana são bem documentados no segmento central da FR, atingindo profusivamente as coberturas metassedimentares meso a neoproterozóicas, e retrabalhando seu embasamento anteriormente consolidado no Evento Transamazônico. A carência de dados geocronológicos confiáveis, bem como a imprecisa comparação com dados obtidos em outras faixas móveis vizinhas ao CSF, resultaram em incertezas quanto à duração desta orogênese, genericamente referida ao intervalo de tempo entre 900 e 450 Ma. Diversos autores descreveram a ocorrência de pelo menos duas etapas de geração de paragêneses metamórficas $\left(\mathrm{M}_{1}\right.$ e $\left.\mathrm{M}_{2}\right)$ no Domínio Autóctone e setor norte do Domínio Inferior, contemporâneas à Deformação Principal e às Fases de Deformação Tardias, respectivamente (Trouw et al 1986, Heilbron et al 1989, Campos Neto 1992). A ocorrência destas duas etapas metamórficas, bem como as idades $\mathrm{Rb} / \mathrm{Sr}$ entre 1,2 e $0,9 \mathrm{Ga}$ resultaram na prévia interpretação de dois eventos orogenéticos, Uruaçuano e Brasiliano. De outro lado, com base nos dados geocronológicos disponíveis para a FR no norte fluminense e sul do Espírito Santo, que se estendem até o Cambriano/Ordoviciano, outros autores (Campos Neto 1992, Campos Neto \& Figueiredo 1992 1995, Figueiredo Campos Neto \& 1993) subdividiram o Ciclo Brasiliano e propuseram a denominação de Orogênese Brasiliano I para o intervalo entre 670-600Ma, e Orogênese Rio Doce para o intervalo entre 590-480 Ma.

Os resultados geocronológicos $\mathrm{U} / \mathrm{Pb}$ obtidos recentemente para o segmento abordado da FR (Machado et al subm.) se situam no intervalo de tempo entre 590 e $492 \mathrm{Ma}$, equivalente ao intervalo da Orogênese Rio Doce acima comentado, embora não haja correspondência direta entre as etapas pré, sin e pós-colisional dos referidos autores. Os novos dados obtidos indicam idades entre 590-563 para a etapa $\mathrm{M}_{1}$ concomitante à Deformação principal $\left(\mathrm{D}_{1+2}\right)$, e 535-520 Ma para a etapa $\mathrm{Mz}$ concomitante à Deformação $\mathrm{D}_{3}$. $\mathrm{O}$ estudo da relação temporal entre a deformação e ao metamorfismo, relacionado à ambientação tectônica das rochas granitóides, permitem interpretar que estas etapas estão relacionadas, respectivamente, aos períodos sin e pós-colisional da Orogênese Brasiliana, corroborando com as propostas de evolução monocíclica de Heilbron (1993), Heilbron et al $(1993,1994)$ e Trouw \& Pankhurst (1993). Estas duas etapas, sin e pós-colisionais da Orogênese Brasiliana, estão registradas em todos os domínios tectônicos do segmento central da FR na área estudada, embora exista um predomínio das idades referentes à etapa metamórfica $\mathrm{M}_{2}$ no setor mais interno, em direção à área costeira do Estado do Rio de Janeiro, refletindo o espessamento crustal após o período colisional. Manifestações granitóides pós-tectônicas se estendem até $492 \mathrm{Ma}$ (Machado et al, subm.). Portanto, com base nos novos dados geocronológicos e no estudo da evolução tectônica do segmento central da FR, subdividiu-se a Orogênese Brasiliana em três etapas tectônicas principais (Fig. 5):

Período Sin-colisional 590-563 Ma;

Período Pós-colisional 535-520 Ma;

Período Pós-tectônico 503-492 Ma;

Algumas idades de minerais metamórficos se estendem até 611 Ma (Machado et al, sumb, e Trouw \& Pankhurst 1993), indicando atividade tectônica precoce. A idade do batólito Serra dos Órgãos de $620 \mathrm{Ma}$, reportada por Delhal et al (1969), também não se enquadra nas novas idades $\mathrm{U} / \mathrm{Pb}$ obtidas, relacionando-se provavelmente ao período pré-colisional.

O Período Sin-colisional (590-563 Ma) $D E F O R$ $M A C ̧ \tilde{A} O$ PRINCIPAL $(D 1+D 2) \quad$ Representa a etapa principal de encurtamento crustal observada no Segmento Central da FR. É representada por duas fases geométricas de deformação $(\mathrm{D} 1+\mathrm{D} 2)$, que geraram as estruturas mais importantes e penetrativas observadas em quase todos os afloramentos de todos os domínio tectônicos, salvo nas zonas de cisalhamento tardias, onde são mascaradas por fases de deformação mais jovens $\left(\mathrm{D}_{3}\right.$ e $\left.\mathrm{D}_{4}\right)$. Em escala regional, a Deformação Principal é responsável pela compartimentação tectônica da faixa, gerada através do empilhamento de diversas escamas de empurrão com transporte tectônico direcionado para a área do Cráton do São Francisco (Fig. 6). Desta tectônica de empurrões resultaram: dobras assimétricas, apertadas a isoclinais, variando de recumbentes a inclinadas; foliação principal observada tanto em escala macro como microscópica, materializada como clivagem ou xistosidade de crenulação, como xistosidade recristalizada ou como forte foliação milonítica; zonas de cisalhamento com formação de milonitos; e na forte lineação de estiramento, além de lineações mineral e de intersecção, boudinage, etc...

No segmento abordado da FR, a análise geométrica e cinemática da deformação principal não é homogénea, destacando-se setores com alta densidade de informações estruturais, e com tratamento geométrico e cinemático já realizado, enquanto que em outros setores as informações estruturais ainda são dispersas. A porção sudeste do segmento abordado carece especialmente de estudos estruturais sistemáticos, o que acaba causando divergências quanto às interpretações cinemáticas. 


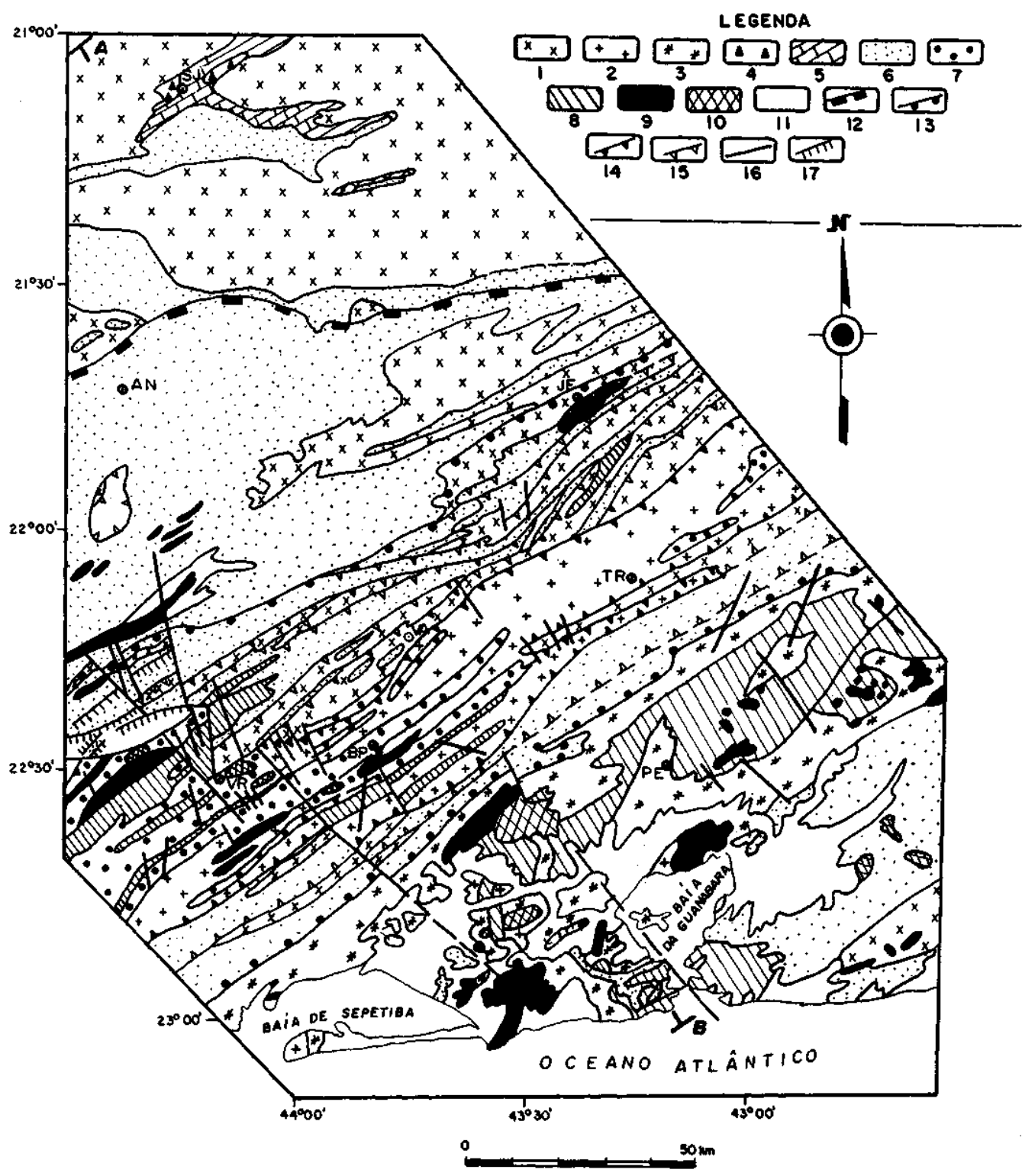

Figura 4 - Mapa Tectônico, na escala ao milionésimo, do Segmento Central da Faixa Ribeira, com as principais unidades litotectônicas discriminadas, l-Embasamento Pré- 1,8 Ga nos domínios Autóctone, Alóctone Inferior e Alóctone Médio; 2Embasamento Pré- 1,8 Ga no Domínio Alóctone Superior; 3- Ortognaisses com posicionamento temporal ainda não definido, provavelmente integrantes do conjunto do embasamento; 4- Ciclos Deposicionais Tiradentes e Lenheiro; 5- Ciclo Deposicional Carandaí; 6- Ciclo Deposicional Andrelândia no Domínio Autóctone e no setor norte dos domínios alóctones Inferior e Médio, e unidades correlatas nos setor sul destes domínios; 7- Metassedimentos do Grupo Paraíba do Sul; 8-Granitóides pré a sin-colisionais da Orogênese Brasiliana; 9- Granitóides tardi-colisionais, pós-colisionais e pós-tectônicos da Orogênese Brasiliana; 10- Rochas Alcalinas Meso-Cenozóicas; 11- Cobertura Meso-Cenozóica; 12-Contato basal do Domínio Alóctone Inferior; 13- Contato basal do Domínio Alóctone Médio; 14- Contato basal do domínio Alóctone Superior; 15- Empurrões internos aos domínios tectônicos; 16- Zonas de cisalhamento normais fanerozóicas; 17- Zonas de cisalhamento direcionais a obliquas fanerozóicas. Abreviatura das Cidades: SJ- S. J. dei Rei, AN-Andrelândia, JF- Juiz de Fora, VA-Valença, TR-Tres Rios, BP-Barra do Piraí, VR-Volta Redonda, PE-Petrópolis.

Figure 4 - Tectonic map of the central segment of the Ribeira belt with the main litho-tectonic associations. Legend: 1- Pré-1.8 Ga basement of AutochtonousLower and Intermediate domains; 2- Pré-1.8 Ga basement of Upper domain; 3- Orthogneisses of unknown ages; 4- Lenheiro and Tiradentes depositional cycles 5- Carandaí depositional cycle; 6 - Andrelândia depositional cycle and probably correlated rocks; 7- Paraíba do Sul group; 8- Pré to syn-collisional Brasiliano gramtoid rocks; 9- Tardi, post collisional and post-tectonic Brasiliano granitoid rocks; 10- Meso/Cenozoic alkaline intrusions; 11- Meso-Cenozoic cover 1214- Basal thrust of the Lower, Intermediate and Upper domains; 15- Subordinated thrusts; 16-Phanerozoic normal shear zones; 17- Phanerozoic transcurrent shear zones. Abbreviation of the localities.

Outro fator gerador de variações no padrão e penetratividade das estruturas da Deformação Principal refere-se às diferenças observadas entre os domínios tectônicos, reflexo das condições mecânicas em diferentes níveis crustais, justapostos ao final da tectônica de empurrões. Heterogeneidades causadas pela partição da deformação também resultam em 


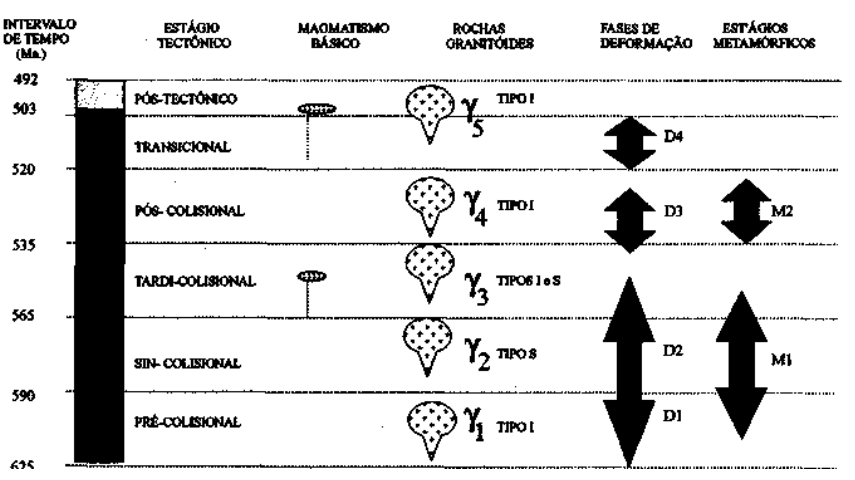

Figura 5 - Diagrama com a subdivisão proposta para a Orogênese Brasiliana, no segmento central da Faixa Ribeira, relacionando suas fases de deformação, etapas metamórficas e rochas granitóides.

Figure 5 - Time diagram with the subdivisions of the Brasiliano orogeny at the central segment of Ribeira belt.

variações no estilo estrutural ao longo deste segmento da FR. Com vistas a sistematizar estas variações, as estruturas da Deformação Principal estão descritas de forma sintética na Tabela 2, em cada domínio tectônico. De forma resumida, apresenta-se abaixo a orientação dos principais indicadores cinemáticos em cada um destes compartimentos.

Deformação Principal no Domínio Autóctone: observa-se uma clara polaridade da deformação principal, cujos efeitos diminuem em direção à área cratônica. Desta forma, nos arredores de São João dei Rei a deformação principal é representada por dobras abertas com clivagem $\mathrm{S}_{2}$ em leque (Valeriano 1985). Nesta região, ainda podem ser reconhecidas diversas estruturas sedimentares primárias (estratificações cruzadas, marcas de onda, etc...). Logo ao sul, a deformação se intensifica e acaba gerando dobras apertadas a isoclinais, com forte clivagem de crenulação plano axial (Valeriano 1985, Heilbron 1984). Próximo ao contato com o Domínio Tectônico Inferior, desenvolve-se uma foliação milonítica com peixes de mica (Bittar 1990, Gonçalves 1989). Estruturas miloníticas geradas na deformação $\mathrm{D}_{2}$ são frequentes nos domínios tectônicos sobrejacentes.

A orientação dos eixos de dobras da deformação principal é aproximadamente E/W (080-120) com caimentos suaves. Lineações de crenulação são frequentes nos litotipos mais micáceos, enquanto que nas intercalações quartzíticas ocorre preferencialmente uma forte lineação mineral e/ou de estiramento. $\mathrm{O}$ padrão assimétrico das dobras $\mathrm{D}_{2}$ e a atitude dos planos axiais definem uma vergência clara em direção ao Cráton do São Francisco.

Deformação principal no Domínio Alóctone Inferior: é dominada pelo dobramento $\mathrm{D}_{2}$, representado por dobras apertadas a isoclinais, identificadas desde a escala microscópica até a escala do mapa. A foliação $S_{2}$ ou $S_{1+2}$ é a estrutura planar mais importante neste compartimento, e morfologicamente varia de uma clivagem de crenulação apertada até uma xistosidade grossa, com raros vestígios da crenulação $\mathrm{D}_{2}$. Estas variações são função do aumento no grau metamórfico para sudeste, em toda faixa, o que facilita a recristalização e o crescimento dos minerais metamórficos, mascarando as microdobras.

A orientação da lineação de estiramento e/ou mineral, em relação aos eixos das dobras $\mathrm{D}_{2}$, varia tanto em escala de afloramento como em escala megascópica, embora esteja sempre contida na foliação $\mathrm{S}_{2}$ ou $\mathrm{S}_{1}+\mathrm{S}_{2}$. Os trabalhos de
Gonçalves (1986), Bittar (1990), Ribeiro et al. (1990) e Nummer (1992) reportam a orientação da lineação mineral no âmbito da folha Barbacena a norte de Arantina (região do DI próximo ao DA). Nesta região, a lineação mineral possui direção preferencial NNW a NNE, e os indicadores cinemáticos apontam para o transporte principal voltado para a área cratônica. A variação, em mapa, da relação angular entre este elemento geométrico e o eixo da dobras $\mathrm{D}_{2}$, sempre medida no plano $\mathrm{S}_{2}$ ou $\mathrm{S}_{1}+\mathrm{S}_{2}$, foi estudada detalhadamente por Heilbron (1993), no setor entre as cidades de Bom Jardim de Minas (MG) e Barra do Piraí (RJ). Ali, próximo ao contato com o Domínio Alóctone Médio sobrejacente, acompanhando a modificação para mergulhos mais íngremes da foliação principal, a lineação mineral passa a assumir ora caimento suave para NE, ora caimento íngreme para SE. Neste segmento, o transporte tectônico indica uma movimentação oblíqua (Heilbron 1993), com uma combinação de indicadores dextrais e inversos. No setor sul/sudeste da região enfocada não existe o mesmo nível de detalhamento nos estudos de orientação e vergência dos elementos estruturais da deformação $\mathrm{D}_{1}+\mathrm{D}_{2}$. Como exemplos de estudos localizados podem ser citados os trabalhos de Valeriano \& Magalhães (1984), Silva et al. (1989) e Silva e Silva (1987) no município do Rio de Janeiro, Machado (1990) na região de Araruama, e Heilbron et al.(1991) e Dios (1993) na região entre Rio Claro e Mangaratiba. Alguns autores sugerem transporte tectônico para NW (Heilbron et al. 1991), enquanto outros indicam vergência oposta para SE (Machado \& Endo 1993). Desta forma, não existe consenso quanto à direção principal do transporte tectônico neste setor da FR.

Deformação Principal no Domínio Alóctone Médio: caracteriza-se por um intenso imbricamento tectônico entre rochas metassedimentares da cobertura e rochas granulíticas do embasamento. Esta interdigitação pode ser verificada tanto em escala de afloramento, especialmente na região da Serra da Mantiqueira, onde são observadas, com frequência, lascas de diversas dimensões (centímetros a dezenas de metros) de rochas granulíticas embutidas no conjunto supracrustal, como na escala de mapa, que se caracteriza por um conjunto de lentes amendoadas na direção NE-SW (Fig. 4 e 5).

A lineação mineral e/ou a de estiramento associa-se à foliação milonítica, caracterizando a deformação principal neste domínio tectônico. Pode ser observada em quase todos os afloramentos, sendo definida pela orientação preferencial de minerais individuais alongados (comumente quartzo, anfibólios, piroxênios), no primeiro caso, ou pelo estiramento de conjuntos minerais, no segundo caso. Nas zonas de deformação mais intensa, a lineação mineral torna-se mais evidente que a foliação $\mathrm{S}_{2}$, e se formam L-tectonitos, como, por exemplo, nas rochas granulíticas do Complexo Juiz de Fora, próximo ao contato com o Domínio Alóctone Superior, entre Conservatória e Barra do Piraí. A orientação da lineação mineral varia muito, embora já predominem atitudes subhorizontais na direção $\mathrm{NE} / \mathrm{SW}$, indicando a importância da componente de movimentação lateral. Em alguns setores deste compartimento, concentram-se medidas down dip da lineação mineral, indicando ainda a componente de encurtamento para NW

Deformação Principal no Domínio Alóctone Superior: Apresenta outro estilo estrutural e diferentes condições metamórficas se comparado ao Domínio Alóctone Médio. A estrutura mais evidente gerada é a xistosidade grossa, definida pelo arranjo de todos os minerais constituintes dos diversos lito- 
Tabela 2 - Caracterização da Deformação Principal no Segmento Central da Faixa Ribeira.

Table 2 - Characterization of the Main Deformational Phase at the central segment of Ribeira belt.

\begin{tabular}{|c|c|c|c|}
\hline \multicolumn{4}{|c|}{ DEFORMAÇÃO PRINCIPAL D1+D2 } \\
\hline Dominio Tectônico & Características Gerais & Foliações e Lineaçōes & Estilo e Orientação das Dobras \\
\hline $\begin{array}{l}\text { - Domínio Autóctone } \\
\text { (DA) }\end{array}$ & $\begin{array}{l}\text { - Polaridade deformacional incluindo } \\
\text { apertamento progressivo das dobras } \\
\text { em direçăa a porção mais interna do } \\
\text { domínio. }\end{array}$ & $\begin{array}{l}\text { - Clivagem ardosiana prơximo à borda } \\
\text { cratônica } \\
\text { - Clivagem a xistosidade de crenulaçăa } \\
\text { apertada em direção ao DI } \\
\text { - Lineação de interseç̧ão nos quartzi- } \\
\text { cos, Lineação de crenulação nos tipos } \\
\text { pelíticos, Lineação mineral paralela } \\
\text { aos eixos das dobras }\end{array}$ & $\begin{array}{l}\text { - Dobras abertas normais com caimen- } \\
\text { to e clivagem ardosiana em leque } \\
\text { proximo à borda cratônica } \\
\text { - Dobras apertadas a isoclinais recum- } \\
\text { bentes a inclinadas em direção à por- } \\
\text { ça mais interna do domínio }\end{array}$ \\
\hline $\begin{array}{l}\text { - Domínio Alóctone } \\
\text { Inferior (Dl) }\end{array}$ & $\begin{array}{l}\text { - Dobras apertadas a isoclinaís } \\
\text { - Redobramento D2 x D1 frequente } \\
\text { - Foliação Principal } \$ 1+2 \\
\text { - Zonas de cisalhamento restritas }\end{array}$ & $\begin{array}{l}\text { - Xistosidade grossa com relictos de } \\
\text { crenulação nos tipos pelíticos } \\
\text { - Xistosidade de crenulaçãa } \\
\text { - Foliação milonítica restrita às Zcs } \\
\text { (com peixes de mica na base do } \\
\text { dominio no setor norte; e com } \\
\text { porfiroclastos manteados e boudins } \\
\text { assimétricos no setor sul) } \\
\text { - Lineação de intersecçăo nos quartzi- } \\
\text { tos, Lineação de crenulação nos tipos } \\
\text { pelíticos, Lineaçăo mineral paralela } \\
\text { ao eixos das dobras }\end{array}$ & $\begin{array}{l}\text { - Redobramento D2 x D1 } \\
\text { - Dobras D2 recumbentes no setor norte } \\
\text { - Dobras D2 reviradas com caimento a } \\
\text { reclinadas no setor norte proximo ao } \\
\text { contato com o DM } \\
\text { - Dobras D2 recumbentes a inclinadas } \\
\text { no setor sul } \\
\text { - dobras em bainha }\end{array}$ \\
\hline $\begin{array}{l}\text { Domínio Alóctone } \\
\text { Médio (DM) }\end{array}$ & $\begin{array}{l}\text { Foliação milonítica com dobras } \\
\text { intra-foliais e muitos indicadores } \\
\text { cinemáticos, especialmente no setor } \\
\text { norte do domńnio } \\
\text { - Interdigitaçăo tectônica entre cober- } \\
\text { tura e embasamento }\end{array}$ & $\begin{array}{l}\text { - Foliaçăo milonítica predominante, } \\
\text { com porfiroclastos tipo sigma e delta, } \\
\text { - boudins rotacionados, duplexes de } \\
\text { foliação, foliaçōes S X C } \\
\text { - Bandamento composicional tectônico } \\
\text { - Forte lineaçăo mineral }\end{array}$ & $\begin{array}{l}\text { Raras dobras megascópicas e predo- } \\
\text { mínio de dobras intrafoliais. } \\
\text { Grande acilindricidade resulta em } \\
\text { variaçãa da orientação das dobras, } \\
\text { desde recumbentes a normais, local- } \\
\text { mente reclinadas }\end{array}$ \\
\hline $\begin{array}{l}\text { - Domínio Al6ctone } \\
\text { Superior (DS) }\end{array}$ & $\begin{array}{l}\text { - Dobras apertadas a abertas } \\
\text { - Xistosidade grossa }\end{array}$ & $\begin{array}{l}\text { - Xistosidade grossa nos tipos gnáissi- } \\
\text { cos } \\
\text { - Xistosidade de crenulação nos tipos } \\
\text { pelíticos } \\
\text { - Lineaç̋es de crenulação e intersecção, } \\
\text { e mais raramente lineação mineral }\end{array}$ & $\begin{array}{l}\text { Dobras apertadas a abertas inclinadas } \\
\text { a recumbentes, menos frequentes } \\
\text { - Crenulaçđes nos tipos pelíticos }\end{array}$ \\
\hline
\end{tabular}

tipos. Contrasta com os outros dois domínios alóctones, possuindo menor ocorrência de dobras, bem como de zonas de cisalhamento. Milonitos associados à deformação principal são encontrados preferencialmente na região de contato com o domínio subjacente, onde a foliação assume também mergulhos mais íngremes, especialmente na Serra da Mantiqueira (Fig. 6). Neste setor, a lineação mineral/estiramento e os indicadores cinemáticos encontrados indicam movimentação oblíqua, dextral e inversa (Heilbron 1993). Além de milonitos e L-tectonitos, esta região de contato caracteriza-se por uma mistura tectônica entre litotipos do Grupo Paraíba do Sul e da Suíte Intrusiva Quirino, com metapelitos da cobertura e granulitos do Complexo Juiz de Fora do Domínio Alóctone Médio, que se distribuem geometricamente como duplexes na escala do mapa (Fig. 4).

Além da assimetria das dobras $\mathrm{D}_{2}$, outros indicadores cinemáticos apontam para uma componente de transporte inverso para NW, apesar da componente direcional dextral (Heilbron et al. 1989). Embora os estudos da cinemática da deformação sejam ainda incipientes neste compartimento, especialmente no setor a sul da Zona de Cisalhamento do Paraíba do Sul, as observações estruturais feitas até o momento indicam que a deformação principal possui vergência homogénea em todo o Domínio Alóctone Superior, constrastando com a proposta de vergência centrífuga (Machado \& Endo 1993). A lineação mineral não é muito desenvolvida neste compartimento. Sua orientação média é subhorizontal na direção NE/SW com transporte dextral, embora também sejam encontradas lineações down dip com transporte do topo para NW. Somente a realização de estudos estruturais mais detalhados neste domínio tectônico poderá esclarecer esta questão.

METAMORFISMO $M_{1}$ A etapa metamórfica $\mathrm{M}_{1}$ atingiu seu ápice de temperatura durante a Deformação Principal $\mathrm{D}_{1}+\mathrm{D}_{2}$ e, portanto, as paragêneses resultantes estão materializadas nas foliações $S_{1}, S_{2}$ ou $S_{1+2}$. De forma geral, o metamorfismo MI aumenta para SE (Fig. 7) e, portanto, nas regiões da Serra do Mar e costeira do Estado do Rio de Janeiro estão registradas suas condições de temperatura máxima representadas pela paragênese cordierita + sillimanita + almandina + $\mathrm{K}$-feldspato, presentes nas unidades pelíticas da cobertura pós-1,8 Ga. No município do Rio de Janeiro, as relações microtectônicas descritas por Pires et al. (1986) indicam que o crescimento de cordierita é tardio em relação aos outros minerais metamórficos. As condições máximas de pressão variam de média a alta, seguidas por uma etapa de menor pressão. Os valores máximos de pressão foram obtidos por Trouw (1992), que reportou dados geotermobarométricos da ordem de $700-900^{\circ} \mathrm{C}$ e $8-10 \mathrm{~Kb}$ para a região de Andrelândia. No Domínio Alóctone Superior, entretanto, o ápice térmico situa-se na fácies anfibolito próximo ao início da anatexia e, 
portanto, leitos leucossomáticos anatéticos em tipos composicionais apropriados coexistem com relíquias de muscovita primária.

As condições de temperatura da etapa $M_{1}$ foram suficientemente altas para causar anatexia generalizada em algumas unidades supracrustais, o que acabou originando a geração de granitóides tipo $\mathrm{S}$. Estes granitóides, sin- $\mathrm{D}_{2}$ a inter- $\mathrm{D}_{2} / \mathrm{D}_{3}$, são frequentes nos domínios alóctones Médio e Superior, onde chegam a assumir dimensões batolíticas. Outros granitóides calcialcalinos $\sin D_{1} / D_{2}$ parecem ter-se formado a partir da fusão parcial de rochas intermediárias com hornblenda, conforme apontam dados litogeoquímicos de diversos autores, sugerindo que esta etapa metamórfica deve ter causado anatexia no embasamento das rochas metassèdimentares, em níveis crustais mais profundos.
Para elaborar o perfil metamórfico simplificado (Fig. 7), com as diversas zonas detectadas principalmente a partir das unidades metassedimentares, foram consultados e compilados os dados de Heilbron (1984), Trouw et al. (1986), Heilbron (1993), Silva (1991), Nogueira (1994), Heilbron et al. (1994), Duarte et al (1994), Pires et al. (1986), Silva et al. (1991). Foram individualizadas as seguintes zonas metamórficas, em parte já apresentadas por Trouw et al (1986) e Heilbron (1993): Biotita, Granada, Cianita, Cianita/Sillimanita, Sillimanita, K-feldspato e Cordierita.

Esta distribuição das zonas metamórficas e os dados geotermobarométricos disponíveis (Trouw 1992) indicam um regime progressivo de pressão alta a intermediária (localmente atinge a fácies granulito em alta pressão, como reportado por Trouw, 1992, na área ao sul de Andrelândia), e um caminho retrogressivo em regime de pressão mais baixa,

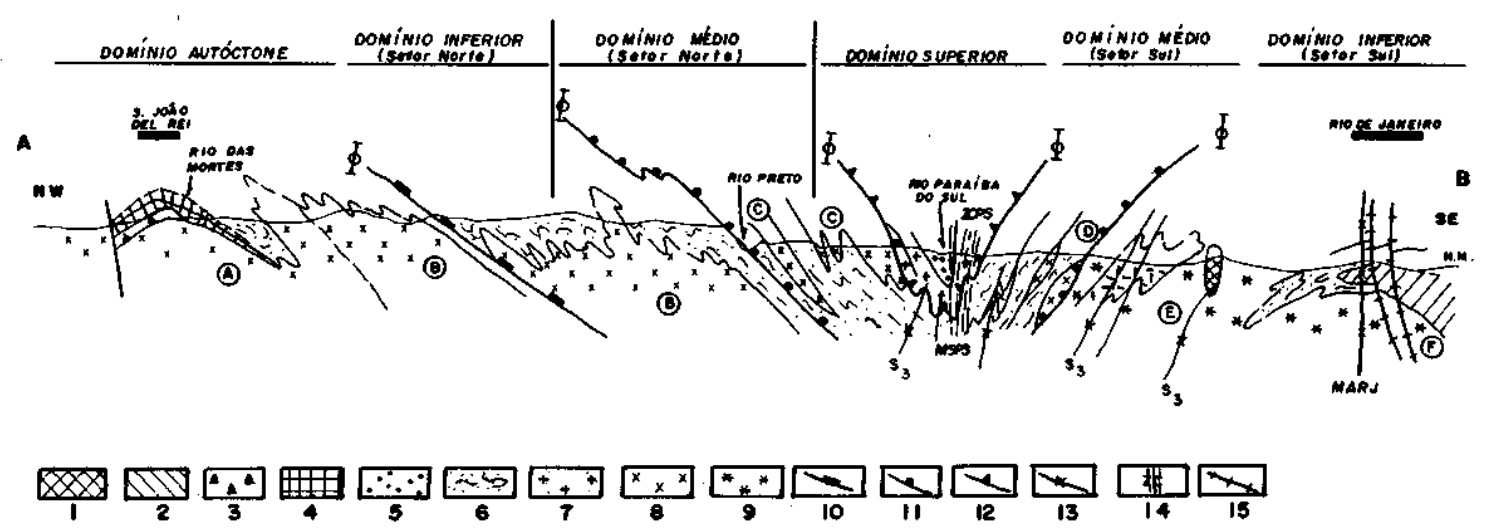

Figura 6 - Seção geológica simplificada NW/SE, na escala ao milionésimo, entre as cidades de S J. dei Rei (MG) e Rio de Janeiro(RJ), com a distribuição e relação estrutural entre as unidades tectônicas discriminadas no mapa tectônico. A notação utilizada é a mesma da Figura 4. As letras indicam as diversas unidades do embasamento Pré-1,8 Ga A-Complexos Barbacena e Divinópolis, B- Complexo Mantiqueira, C-Complexo Juiz de Fora, D-Embasamento não discriminado, E-Complexo Rio Negro, F-Unidade ou Série Inferior. Figure 6 - Geological section of the central segment of the Ribeira belt between São João dei Rei (MG) and Rio de Janeiro (RJ) cities, with the structural relationship of the litho-tectonic associations. Legend similar to figure 4. Letters indicate the pré-1.8 Ga basement units: A- Barbacena and Divinópolis complexes; B- Mantiqueira complex; C- Juiz de Fora complex; D- indiscriminated basement; E- Rio Negro complex and F- Lower series.

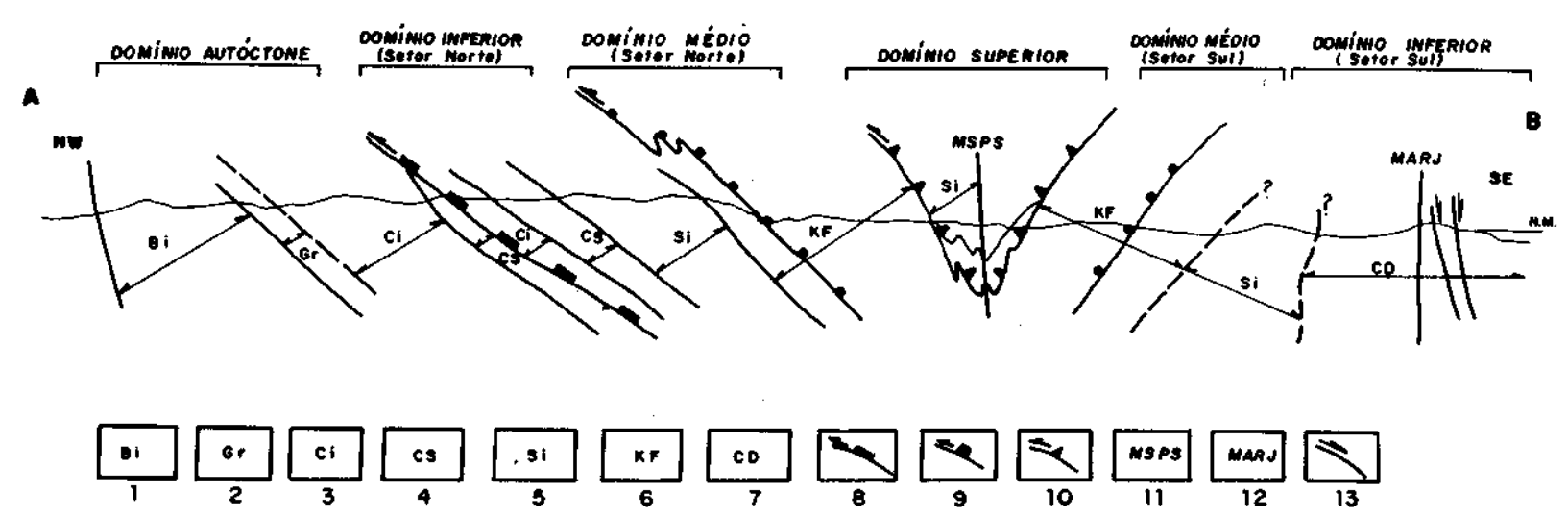

Figura 7 - Seção geológica com a distribuição das zonas metamórficas relacionadas ao metamorfismo principal $M_{1}$, extraídas dos mapas metamórficos de Trouw et al. 1986; Heilbron, 1984 e 1993. 1- Zona da Biotita, 2- Zona da Granada, 3- Zona da Cianita, 4- Zona da Cianita-Sillimanita, 5- Zona da Sillimanita, 6-Zona do K-feldspato, 7- Zona da cordierita (relacionada a $\mathrm{M}_{2}$ ?), 8- Contato basal do Domínio Alóctone Inferior, 9-Contato basal do Domínio Alóctone Médio; 10- Contato basal do Domínio Alóctone Superior, 11- Megassinforma do Rio Paraíba do Sul, 12-Megantiforma do Rio de janeiro, 13-Zonas de cisalhamento rúpteis fanerozóicas.

Figure 7 - Geological section with the distribution of the metamorphic zones related to Mi metamorphic stage, based on Trouw et al. (1986); Heilbron (1984 1993). Legend: 1- Biotite zone; 2- Garnet zone; 3- Kyanite zone; 4- Kyanite-sillimanite zone; 5-Sillimanite zone; 6- K-feldspar zone; 7- Cordierite zone; 8-10Basal thrusts of Lower, Intermediate and Upper domains; 11- Paraíba do sul mega-synform; 12- Rio de Janeiro mega-antiform; 13- Phanerozoic brittle shear zones. 
sugestivos para um caminho PTt do tipo ITD (isothermal decompression, Harley 1989) para o setor norte do Domínio Inferior. A falta de dados geotermo-barométricos para os outros domínio tectônicos, e mesmo sobre o setor sul do Domínio Inferior, na área costeira do estado do Rio de Janeiro, não permitem a elaboração de discussões mais regionais sobre o caminho PTt da etapa metamórfica $\mathrm{M}_{1}$.

As paragêneses de mais alta pressão reportadas para a região de Liberdade, por Trouw (1992) e Silva (1990), são reliquiares em relação às paragêneses acima descritas, indicando terem sido geradas no início da etapa metamórfica $M_{1}$. As idades $\mathrm{Sm} / \mathrm{Nd}$ para esta paragênese eclogítica, ao redor de $600 \mathrm{Ma}$ (Trouw \& Pankhurst 1993), assim como as poucas idades U/Pb de minerais metamórficos, entre 590 e $611 \mathrm{Ma}$ (Machado et al, subm), indicam a precocidade destas paragêneses de alta pressão. Como exemplos descritos por estes autores, podem ser citados simplectitos de granada + clinopiroxênio entre cristais de ortopiroxênio e plagioclásio encontrados em ortogranulitos do embasamento pré- $1,8 \mathrm{Ga}$, a sul de Andrelândia, próximo a cidade de Liberdade. Outro caso de paragênese interpretada como de mais alta pressão (fácies granulito de alta pressão) é o exemplo com cianita + K-feldspato + granada + quartzo em leucognaisses do Ciclo Deposicional Andrelândia (Trouw 1992).

$\mathrm{O}$ zoneamento metamórfico $\mathrm{M}_{1}$ é inverso, ou seja, as zonas de mais alta temperatura estão estruturalmente superpostas às de menor temperatura (Fig. 7). As isógradas metamórficas truncam o acamamento sedimentar paralelo à foliação $\mathrm{S}_{1}$. A ocorrência de zonas de maior temperatura para sudeste parece indicar maior espessamento crustal nesta direção. Os empurrões tardios em relação à deformação principal, tais como o contato basal do Domínio Alóctone Inferior, no setor norte da região abordada, causam truncamentos nas isógradas previamente estabelecidas, resultando em descontinuidades metamórficas (Gonçalves 1986 e Trouw et al. 1986). O padrão gerado (Heilbron 1993), no qual zonas de menor temperatura se repetem (zona da cianita, zona da cianita/sillimanita) e novamente zona da cianita (vide Fig. 7), implica na pretérita inversão das isógradas metamórficas.

Tal como apontado por Heilbron (1993), o padrão do zoneamento metamórfico observado nesta etapa metamórfica sugere o modelo de transferência de calor de nappes quentes (modelo ferro de engomar, Brunel \& Kienast 1986, Mohan et al. 1989), combinado com cisalhamento dúctil das isógradas, como o mais adequado para este segmento da FR. Este modelo também é consistente com o provável transporte de fluidos, necessários ao processamento do retrometamorfismo nos granulitos do Complexo Juiz de Fora, a partir do conjunto da cobertura do domínio tectônico subjacente (Dl), implicando na migração de fluidos "para cima", transferidos do Domínio Alóctone Inferior para o Domínio Alóctone Médio. Esta hipótese é reforçada pela maior intensidade do retrometamorfismo na base deste último domínio tectônico.

Quando as rochas do embasamento dos conjuntos supracrustais já possuíam grau metamórfico mais elevado que o estabelecido na etapa $\mathrm{M}_{1}$, como por exemplo nas lascas tectônicas de rochas granulitos do Complexo Juiz de Fora no DM, observa-se a formação de paragêneses retrógradas, tais como: a) ortopiroxênio com fraturas e bordas substituídas por hornblenda e biotita; b) clinopiroxênio com bordas de hornblenda e apatita, chegando, em alguns casos, a formar tremolita/ actinolita; c) plagioclásios zonados com bordas menos cálcicas; e d) hornblenda com fraturas e bordas biotíticos. Em alguns casos, a intensidade maior da deformação $\mathrm{D}_{2}$ e do metamorfismo $M_{1}$ chega a obliterar estas paragêneses de maior temperatura, transformando as rochas granulíticas transamazônicas em hornblenda gnaisses muito miloníticos, com raras relíquias de ortopiroxênio e/ou clinopiroxênio. Por outro lado, em diversos afloramentos do conjunto dos ortogranulitos do Complexo Juiz de Fora, especialmente aqueles situados no setor NE, entre Juiz de Fora e Mar de Espanha, e localmente em Três Rios, observou-se o aparecimento de cristais de granada e hornblenda nas bordas de cristais de clinopiroxênio, indicando que as condições de pressão de carga atingidas na etapa $M_{1}$ foram superiores às estabelecidas durante o pulso metamórfico do embasamento.

MAGMATISMO $\left(\delta_{1}\right.$ a $\left.\delta_{3}\right)$ Os granitóides gerados nesta época sofreram os efeitos da etapa principal de deformação compressiva da Orogênese Brasiliana. São corpos gnaissificados, portadores da xistosidade $\mathrm{S}_{2}$ ou $\mathrm{S}_{1+2}$ e de lineação mineral, e possuem formas tabulares, alongadas segundo a direção da xistosidade principal. Texturalmente são xistosos e possuem estrutura gnáissica, podendo transicionar ainda para rochas miloníticas nas regiões com deformação mais extrema, ou para tipos pouco deformados com texturas ígneas ainda preservadas. Estas texturas reliquiares são encontradas preferencialmente no centro dos corpos mais possantes. $\mathrm{O}$ mapeamento detalhado de alguns destes corpos revela a ocorrência de apófises nas rochas encaixantes, bem como xenólitos destas, como por exemplo no Gnaisse Facoidal do município do Rio de Janeiro.

No quadro esquemático que acompanha a Figura 8 , foi feita uma subdivisão temporal tentativa entre granitóides $\delta_{1}$ e $\delta_{2}$, de acordo com as determinações geocronológicas disponíveis, ou das estruturas tectônicas encontradas (foliação $S_{1}$ e dobras $\mathrm{D}_{2}$, ou somente foliação $\mathrm{S}_{2}$ ).

Batólito Serra dos Órgãos $\left(\delta_{1} / \delta_{2}\right)$ Trata-se do granitóide brasiliano de maior expressão areal no segmento da FR considerado. Intrude ortognaisses interpretados como pertencentes ao embasamento pré- $1,8 \mathrm{Ga}$, no setor sul do Domínio Alóctone Inferior. Sua composição varia entre granito e granodiorito, tendo biotita e hornblenda como minerais máficos. Possui composição calcioalcalina, metaluminosa, representando magmatismo tipo I, (Grossi Sad et al. 1985, Machado Filho et al 1983, Junho 1991, Machado \& Demange 1992). Numerosos enclaves máficos e restos das rochas encaixantes podem ser encontrados em seu interior. Corpos tabulares de leucognaisse ocorrem associados ao granitóide. As idades $\mathrm{U} / \mathrm{Pb}$ de Delhal et al (1969) indicam formação precoce, há $620 \mathrm{Ma}$, na Orogênese Brasiliana. No entanto, suas características estruturais parecem apontar para posicionamento mais tardio em relação à etapa colisional. Possui a foliação principal $\mathrm{S}_{2}$ que se encontra dobrada pelas fases de deformação tardias. Nesta proposta de integração regional, com base na idade $\mathrm{U} / \mathrm{Pb}$ disponível, este granitóide foi posicionado na etapa pré-colisional.

Gnaisse Facoidal $\left(\delta_{l}\right)$ Ou Batólito Niterói (Machado \& Demange 1992) intrude metassedimentos e ortognaisses. Aflora no setor sul do DI, formando os principais afloramentos rochosos dos município de Niterói e do Rio de Janeiro, próximo à costa. Apesar de já ter sido considerado uma rocha derivada da blastese de gnaisses (Lamego 1937), os trabalhos de detalhe realizados no Rio de Janeiro (Pires et al. 1982, Silva \& Silva 1987, Silva et al 1991, Heilbron et al 1993b) 
confirmam seu caráter intrusivo, através da identificação de xenólitos e xenocristais, além de apófises com granulometria mais fina que invadem discordantemente suas encaixantes. Consiste em um granito porfiróide gnaissificado, com megacristais de K-feldspato ( 5 a $8 \mathrm{~cm}$ em média, podendo atingir $10-12 \mathrm{~cm}$ de comprimento). A proporção matriz/pórfiros varia muito, bem como o tamanho, forma e orientação dos megacristais de K-feldspato. A atuação preferencial da deformação $\mathrm{D}_{2}$, nas bordas ou em zonas de cisalhamento no centro do corpo, define porções onde os megacristais sofrem deformação e recristalização dinâmica, assumindo textura augen. A combinação das variações texturais e granulométricas da época da cristalização magmática, com as modificações causadas pela deformação $\mathrm{D}_{2}$, resultam em variedades de texturas transicionais entre si. No município do Rio de Janeiro ocorrem manchas irregulares (de diversas proporções) com coloração esverdeada, portadoras de ortopiroxênio e feldspatos esverdeados (manchas charnockíticas), com a mesma textura do restante do corpo. Esta manchas foram interpretadas por Heilbron et al. (1993b) como originadas por variações na pressão parcial de $\mathrm{CO}_{2}$, durante a cristalização do corpo magmático, que favoreceram o crescimento de ortopiroxênio em detrimento de fases minerais hidratadas (charnockitóides ígneos). Sua composição química indica tratar-se de granito calcialcalino, metaluminoso (Machado \& Demange 1992).

Granitóide Rio Turvo $\left(\delta_{2}\right)$ Aflora a leste e nordeste da Bacia de Resende, entre Nossa Senhora do Amparo e Volta Redonda, no setor norte do Domínio Alóctone Médio. Seus contatos gradacionais com as unidades supracrustais do Ciclo Deposicional Andrelândia, e a frequente ocorrência de enclaves de rochas refratárias (calcissilicáticas, gonditos, quartzito, sillimanita granada gnaisses), são indicativos de sua derivação a partir da fusão parcial do conjunto metassedimentar. Apresenta-se como um granito porfiróide com cristais de microclina de 1,5-2 cm de comprimento, além de andesina, quartzo, biotita, muscovita e granada. Texturalmente exibe forte foliação milonítica e outros indícios de deformação intensa, tais como porfiroclastos de feldspato com franjas de recristalização assimétrica e foliações S-C. Machado et al. (subm.) obtiveram idades $\mathrm{U} / \mathrm{Pb}$ de $579+/-6 \mathrm{Ma}$ (idade concordante em monazita) e $551 \mathrm{Ma}$ (idade discordante em titanita), para este corpo granitóide, em afloramento situado a norte de Volta Redonda.

Granitóide Serra da Concórdia $\left(\delta_{2}\right)$ Aflora no Domínio Tectônico Superior e intrude ortognaisses da Suíte Quirino e gnaisses pelíticos do Grupo Paraíba do Sul. É representado por um granitóide deformado, com forte foliação milonítica, que sustenta a Serra da Concórdia, localizada a WSW da cidade de Valença. Em termos composicionais e aspectos texturais, assemelha-se ao Granitóide Rio Turvo, descrito anteriormente, inclusive no seu posicionamento temporal, refletindo o auge metamórfico neste domínio. É composto por microclina, plagioclásio, quartzo, biotita, e granada, com zirção e opacos como minerais acessórios.

Leucogranitos tipo $S\left(\delta_{2}\right)$ Lentes e stocks deformados de granitóides do tipo $\mathrm{S}$, a duas micas e portadores de turmalina, foram descritos intrudindo tanto metassedimentos do Ciclo Deposicional Andrelândia, no Domínio Alóctone Inferior (Junho 1993), como intrudindo o Grupo Paraíba do Sul, no Domínio Alóctone Superior (Almeida et al. 1993). No primeiro caso, suas relações com as rochas encaixantes indi- cam formação quase in situ, a partir da fusão parcial dos metassedimentos encaixantes. No segundo caso, são alóctones e possuem contatos bruscos com as encaixantes. Nas regiões de maior deformação, o feldspato transforma-se em muscovita e a rocha assume textura xistosa.

Granitóide Matias Barbosa $\left(\delta_{2}\right)$ Aflora no setor norte do Domínio Alóctone Médio (Fig. 8). Possui composição monzonítica a granodiorítica, forte xistosidade, por vezes milonítica, e enclaves de biotita gnaisse e rochas calcissilicáticas. Apresenta estruturas migmatíticas estromáticas e nebulíticas, com leucossomas ricos em anfibólio grosso (Duarte et al. 1994).

Na segmento da FR abordado ocorrem ainda rochas granitóides com características de posicionamento estrutural tardio em relação à etapa colisional, foram classificadas como tardi-colisionais $\left(\delta_{3}\right)$. Predominam granitóides tipo I com rochas básicas associadas, embora também tenham sido encontrados corpos menores tipo S.

Granada Charnockitóide Possui composição granítica com granada e ortopiroxênio, granulometria média a grossa e coloração esverdeada. Foi descrito por Duarte et al. (1994) e aflora no Domínio Alóctone Médio, em Juiz de Fora (Fig. 8). Forma um batólito ovalado e intrude metassedimentos pelíticos na fácies granulito. Possui xenólitos parcialmente digeridos de rochas metassedimentares e de ortogranulitos do Complexo Juiz de Fora.

Granitos Serra do Lagarto e Pedra Selada Constituem corpos alongados na direção NE/SW e intrudem ortognaisses e metassedimentos no setor norte do Domínio Alóctone Inferior. Possuem composição granítica e textura porfiróide, com megacristais subeuédricos de K-feldspato de até $12 \mathrm{~cm}$ de comprimento. A proporção entre megacristais e matriz varia muito; a matriz é rica em biotita, com menores proporções de quartzo, plagioclásio e K-feldspato. Enclaves máficos ricos em anfibólio e lentes quartzo-dioríticas são comuns. O pluton Serra do Lagarto apresenta foliação nas bordas, embora os megacristais não mostrem sinais de deformação (como, por exemplo, forma augen ou sombras de pressão). Esta foliação, interpretada como resultante da combinação de fluxo magmático com efeitos da deformação principal, é ainda dobrada pela deformação $\mathrm{D}_{3}$ subsequente. As relações sumarizadas acima indicam o posicionamento temporal deste corpo granitóide ao final da deformação $\mathrm{D}_{2}$. Os dados litogeoquímicos apresentados por Heilbron (1993) indicam composição calcioalcalina, metaluminosa, com elevados teores em potássio. A assinatura dos elementos terras raras indica enriquecimento nos elementos leves (La/Lu entre 190 e 560) e anomalia negativa de Európio. Sua associação com enclaves básicos corrobora sua classificação como granitóide Tipo-I.

Suite Taquaral Aflora como dois corpos alongados a sul da Bacia de Resende, encaixados nos metassedimentos do Grupo Paraíba do Sul. Compreende uma complexa suíte magmática representada por quartzo-dioritos, meso a melanocráticos, com granulometria média a fina, associados a granitos cinzentos xistosos, com granulometria média a grossa. Leucossomas com megacristais de hornblenda e titanita e apófises de granito porfiróide completam o quadro litológico desta suíte.

O período Pós-colisional (535-520 Ma) DEFORMAÇÕ ES TARDIAS Em todos os domínios tectônicos 

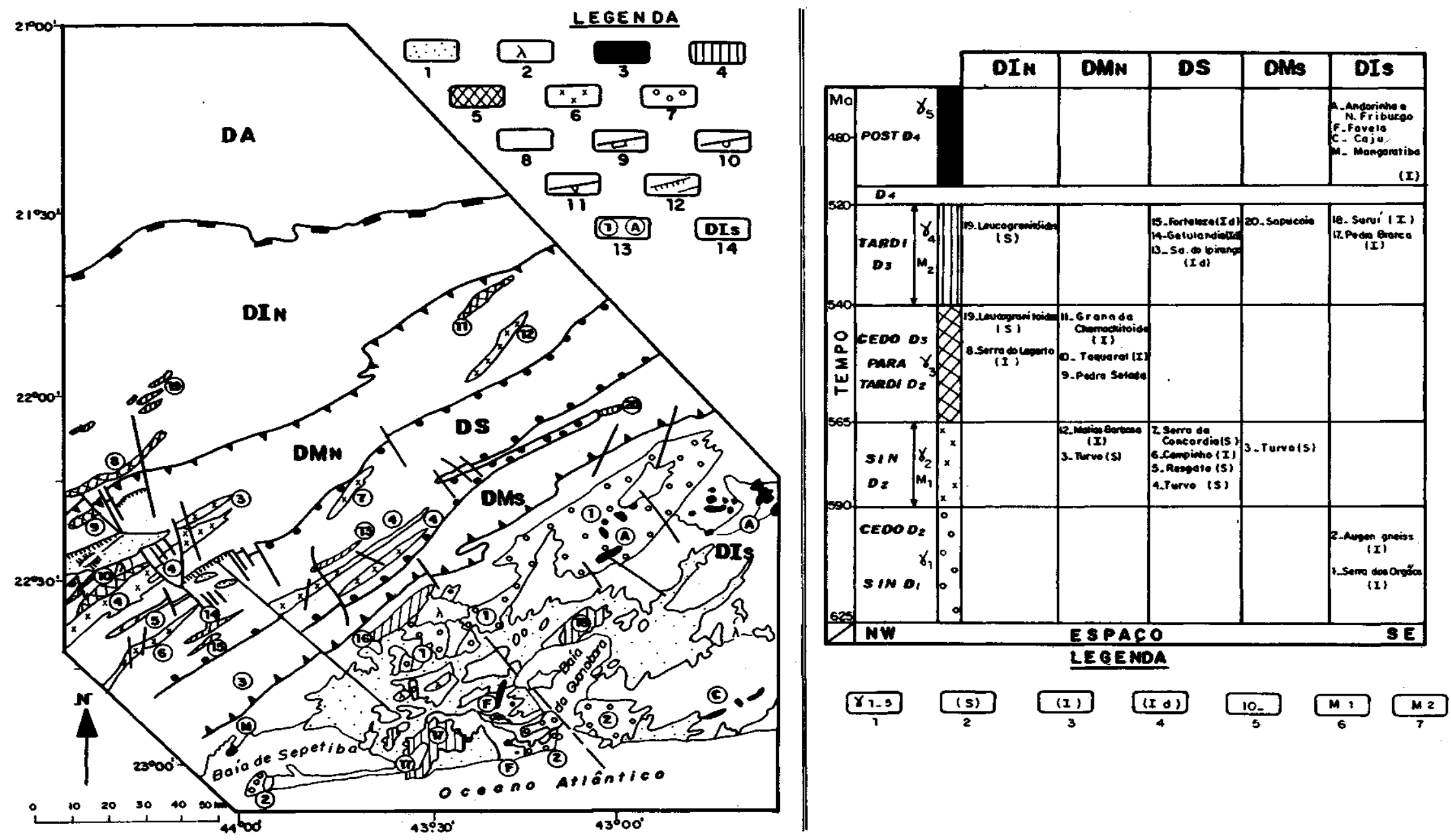

Figura 8 - Mapa tectônico com a localização dos granitóides relacionados à Orogênese Brasiliana, discriminados com relação ao seu posicionamento relativo às fases de deformação e a sua característica geoquímica. Simbologia: 1- Coberturas Meso-Cenozóicas, 2-Rochas alcalinas Meso-Cenozóicas, 3- Granitos Pós-tectônicos, 4- Granitos tardi-D $D_{3}$, 5- Granitos tardi- D, a inter $D_{2}-D_{3}$, 6- Granitos Sin-D, 7- Granitos sin $D_{l}$ a pré $D_{l}$, 8-unidades precambrianas não discriminadas, 9- Contato basal do Domínio Alóctone Inferior. W- Contato basal do Domínio Alóctone Médio; 11- Contato basal do Domínio Alóctone Superior, 12- Zonas de cisalhamento rapteis fanerozóicas, 13- Numeração relativa ao diagrama espaço x tempo, 14-Denominação dos compartimentos tectônicos. Acompanha o diagrama espaço x tempo, contendo a distribuição dos granitóides em relação aos compartimentos tectónicos. Simbologia: l- Posicionamento temporal relativo das rochas granitóides, 2- granitóides tipo S, 3- Granitóides tipo I, 4- granitóides tipo I diferenciado, 5-Numeração relativa ao mapa, 6- Etapa metamórfica M, 7- Etapa metamórfica $M_{2}$

Figure 8 - Tectonic map with the spatial and temporal distribution of the Brasiliano orogeny related granitoid rocks. Legend 1- Meso/Cenozoic cover; 2- Meso/Cenozoic alkaline rocks; 3- Post-tectonic granitoids; 4- Tardi-D3 granitoids; 5- Tardi D2 to inter D2-D3 granitoids, 6- Syn-D2 granitoids, 7- Syn-Dl to Pre Dl granitoids; 8- Precambrian rocks, 9-11 Basal thrusts of Lower, Intermediate and Upper domains; 12- Phanerozoic brittle shear zones, 13- Number related to the nomenclature presented on the $x$ space diag 6- Sym 
deste segmento da FR foram encontradas estruturas posteriores à foliação principal. Estas estruturas foram agrupadas, com base em critérios geométricos, nas fases de deformação $D_{3}$ e $\mathrm{D}_{4}$. Os efeitos da deformação $\mathrm{D}_{4}$ só foram observadas nos dos arredores de Bom Jardim de Minas para sul/sudeste. No setor norte do Domínio Alóctone Inferior e no Domínio Autóctone ainda não foram descritas estruturas $\mathrm{D}_{4}$.

Deformação $D_{3}$ Após o intenso encurtamento crustal resultante do empilhamento das diversas escamas tectônicas durante a deformação principal, o segmento central da FR sofreu os efeitos da deformação $\mathrm{D}_{3}$, que resolveu a contínua compressão através do redobramento de todas as estruturas previamente formadas. Tal deformação gerou dobras empinadas abertas a apertadas, subordinadamente isoclinais, com eixos NE/SW com caimento subhorizontal e planos axiais com mergulhos íngremes para SE ou NW.

Dentre as dobras de maior porte geradas nesta fase de deformação podem ser mencionadas a Megassinforma do Rio Paraíba do Sul (Heilbron et al. 1991), cujo traço axial está situado próximo a calha deste rio, e a Megantiforma do Rio de Janeiro, cujo traço axial se extende desde o município do Rio de Janeiro (a sudoeste) até Lumiar, já na Serra do Mar (a nordeste). Estas dobras em escala regional perturbam o padrão estrutural estabelecido ao final da deformação principal, e podem ser facilmente visualizadas tanto em mapa (Figs. 3 e 4) como em perfil (Fig. 6). A megassinforma do Rio Paraíba do Sul já foi mencionada por diversos autores (Lamego 1936, Rosier 1957, Ebert 1957, Machado Filho et al 1983, Machado 1983), e mais recentemente abordada por Heilbron et al. (1991).

Outra importante estrutura $\mathrm{D}_{3}$ regional é a Zona de CisaIhamento do Rio Paraíba do Sul, já denominada de Além Paraíba no setor centro-norte fluminense (Campanha \& Ferrari 1984, Chrispim \& Tupinambá 1989, Dayan \& Keller 1989). Diversos estudos realizados nesta zona de cisalhamento indicam importante componente de movimentação dextral, além de movimentação vertical inversa. Mais recentemente, seguindo a terminologia mais moderna, foi redefinida como uma zona de cisalhamento com caráter transpressivo (Chrispim \& Tupinambá 1989, Ebert et al. 1991, Corrêa Neto et al. 1993, Heilbron 1993, Machado \& Endo 1993). Os trabalhos detalhados de Corrêa Neto et al. (1993), na região entre Três Rios e Sapucaia, indicam a existência de uma estrutura em flor positiva, com um pop up de sua área central. Em outras zonas de cisalhamento $\mathrm{D}_{3}$, verificou-se que a componente vertical inversa também é importante, causando inclusive descontinuidades metamórficas, como descrito na zona de cisalhamento do Pombeiro ou Três Corações (Heilbron 1984, Almeida 1994), situada a oeste da região aqui abordada. Outras zonas de cisalhamento $\mathrm{D}_{3}$, de menor expressão, podem ser encontradas em todos os domínios estruturais, e indicam a partição da deformação. Apesar de existirem estimativas de grandes rejeitos horizontais, desde muitas dezenas a centenas de quilómetros, o mapeamento geológico detalhado realizado até o presente não indica que a movimentação lateral tenha sido desta magnitude, pois os contatos litológicos são pouco deslocados nos dois blocos separados por estas zonas de cisalhamento. Recentemente, Almeida (1994), com base na separação lateral entre importantes contatos litológicos, obteve para a Zona de Cisalhamento Três Corações uma estimativa entre 11 e $18 \mathrm{Km}$ para a componente de rejeito lateral máxima, sem computar-se a importante componente de rejeito vertical.
Em escala de afloramento, a morfologia das dobras Ds varia muito, possuindo perfis desde abertos, praticamente sem nenhuma foliação plano axial associada, até dobras apertadas com forte clivagem de crenulação plano axial. No interior das zonas de cisalhamento $\mathrm{D}_{3}$, as dobras chegam a possuir perfis isoclinais e a foliação milonítica $\mathrm{S}_{3}$ torna-se a estrutura planar mais importante, transpondo a foliação principal.

A orientação dos elementos estruturais, especialmente dos eixos das dobras $\mathrm{D}_{3}$, varia muito em função da atitude e orientação da xistosidade $S_{2}$ anteriormente formada. Assim, quando a superfície envoltória desta xistosidade possui mergulhos íngremes, as dobras $\mathrm{D}_{3}$ tendem a ser reclinadas ou inclinadas, enquanto que nos setores em que a foliação $\mathrm{S}_{2}$ tem atitude sub-horizontal, o redobramento $\mathrm{D}_{3}$ é predominantemente normal ou empinado. De outro lado, como descrito por Heilbron (1993) para a região de contato entre os domínios alóctones Inferior e Médio na Serra da Mantiqueira, onde a foliação 82 já possuía atitudes subparalelas à futura direção 83 , verificou-se simplesmente o apertamento das estruturas anteriormente formadas, sendo raras as dobras $\mathrm{D}_{3}$. Esta variação na orientação das dobras $\mathrm{D}_{2}$ e $\mathrm{D}_{3}$ gera diversos padrões de redobramento, desde em laço até domos e bacias, e subordinadamente do tipo cogumelo.

A xistosidade de crenulação $\left(\mathrm{S}_{3}\right)$ desenvolve-se especialmente em litotipos mais micáceos, como nos pelitos da cobertura aflorantes no Domínio Autóctone e setor norte do Domínio Alóctone Inferior; nos níveis muito biotíticos da Suíte Granitóide Quirino no Domínio Alóctone Superior; e em níveis melanossomáticos de todos os litotipos estudados. Nos quartzitos grossos e nos gnaisses muito quartzosos, em todos os domínios tectônicos, observa-se o desenvolvimento da clivagem disjuntiva $\mathrm{S}_{3}$. Nos afloramentos ocorre corno fraturas espaçadas, na ordem de centímetros, e possui distribuição em leque com relação às dobras $\mathrm{D}_{3}$. Associada à geração das foliações Ss acima descritas, observou-se, em alguns afloramentos, a formação de lineações de crenulação e interseção, sempre paralelas aos eixos das dobras. Como já mencionado anteriormente, a deformação $\mathrm{D}_{3}$ não produziu uma xistosidade penetrativa em escala regional, com exceção das zonas de cisalhamento $\mathrm{D}_{3}$, onde é encontrada uma foliação milonítica associada.

Deformação $D_{4}$ Esta fase de deformação gerou dobras abertas a suaves, associadas a zonas de cisalhamento dúcteis/ rúpteis. As estruturas resultantes não se distribuem de forma homogénea neste segmento da FR, e tendem a se concentrar em zonas restritas, como nos arredores de Santa Rita do Jacutinga, Valença, Juiz de Fora (Heilbron 1993, Heilbron et al. 1994, Nogueira 1993, Duarte et al 1994) e área metropolitana do Rio de Janeiro (Valeriano \& Magalhães 1984, Silva et al 1991, Heilbron et al 1993b).

A atitude destas zonas de cisalhamento, paralelas aos planos axiais das dobras $\mathrm{D}_{4}$, possui direção entre 320/030 com mergulhos subverticais para E ou W. Possuem movimentação preferencial direcional sinistrai, com pequenos componentes de rejeito vertical, sendo que, via de regra, o bloco leste é o bloco abatido. Machado (1984) decreveu pela primeira vez esta fase de deformação, por ele denominada $\mathrm{F}_{4}$, ortogonal às fases de deformação anteriores, resultando em padrões de interferência do Tipo 1. Não existem estudos detalhados das estruturas desta fase de deformação. Entretanto, Heilbron (1993) sugere um provável regime transtensional em um nível crustal mais raso, na transição entre os campos dúctil e rúptil. 
METAMORFISMO $\mathrm{M}_{2}$ A recristalização e/ou o crescimento de minerais metamórficos contemporâneos à fase de deformação $\mathrm{D}_{3}$ são atribuídos à etapa metamórfica $\mathrm{M}_{2}$. Heilbron (1993) discutiu sobre o intervalo de tempo existente entre estas etapas metamórficas. De um lado, $\mathrm{M}_{2}$ poderia estar relacionada ao período tardi a pós-colisional (pós- $\mathrm{M}_{1}$ ), o que resultaria num pequeno intervalo de tempo entre estas etapas metamórficas. Por outro lado, alguns dados $\mathrm{Rb} / \mathrm{Sr}$ disponíveis na literatura (Heilbron et al. 1989, Campos Neto 1992) atribuem para $\mathrm{M}_{1}$ e $\mathrm{M}_{2}$ idades uruaçuanas e brasilianas, repectivamente. As idades uruaçuanas foram obtidas principalmente em metassedimentos, e referem-se às regiões de São João dei Rei e Andrelândia (Heilbron et al. 1989); e Itapira (Tassinari \& Campos Neto 1989, Campos Neto et al. 1990, Campos Neto 1992). Entretanto, tal como discutido por Heilbron (1993) e Trouw \& Pankhurst (1993), a maioria dos dados geocronológicos existentes, assim como a evolução tectono-metamórfica descrita para a FR, apontam para a primeira possibilidade, ou seja $\mathrm{M}_{2}$ estaria relacionado ao período pós-colisional. Neste caso, os valores mesoproterozóicos obtidos deveriam representar idades híbridas, herdadas do embasamento e parcialmente rejuvenescidas na Orogênese Brasiliana. A obtenção de dados geocronológicos mais retentivos (idades $\mathrm{U} / \mathrm{Pb}$ ) por Machado et al. (subm.), na faixa entre 535 e $520 \mathrm{Ma}$, indicam que $\mathrm{M}_{2}$ está relacionado ao período pós-colisional da Orogênese Brasiliana (Fig. 5).

A temperatura máxima atingida na etapa metamórfica $\mathrm{M}_{2}$ também aumenta para sul/sudeste. Desta forma, no DA e segmento norte do DI, $\mathrm{M}_{2}$ gerou paragêneses da fácies xisto verde, retrógradas em relação às paragêneses $\mathrm{M}_{1}$. $\mathrm{O}$ crescimento de clorita, biotita e cloritóide nas charneiras de microdobras $\mathrm{D}_{3}$, ou nas bordas de estaurolitas e granadas, registrado nos xistos do Ciclo Deposicional Andrelândia por diversos autores, exemplificam esta etapa metamórfica no setor norte do segmento central da FR.

A partir do contato basal do Domínio Alóctone Superior, para sul, a temperatura da etapa $\mathrm{M}_{2}$ aumenta, causando a recristalização dinâmica de minerais na xistosidade $S_{3}$, especialmente nas zonas de cisalhamento desta fase de deformação. A ocorrência de leucossomas anatéticos, bem como o aumento na proporção de granitóides $\delta_{3}$ e $\delta_{4}$, com posicionamento temporal relativo inter- $\mathrm{D}_{2} / \mathrm{D}_{3}$ a Sin- $\mathrm{D}_{3}$ (Fig. 8), também indicam aumento na temperatura de $\mathrm{M}_{2}$ para sul. Este fato também é registrado nas idades $\mathrm{U} / \mathrm{Pb}$ de minerais metamórficos obtidas por Machado et al. (subm.). Estes autores só obtiveram idades para o metamorfismo a partir do contato entre os domínios alóctones Médio e Superior para sul, em direção à região costeira do Estado do Rio de Janeiro. O fato de não se encontar o desenvolvimento da foliação $S_{3}$ regional neste setor da FR, sugere que possa ter ocorrido, pelo menos em parte, recristalização da foliação principal também durante a etapa $\mathrm{M}_{2}$.

A relação da etapa metamórfica $\mathrm{M}_{2}$ com o intervalo de tempo após o empilhamento causado pela deformação Principal $\left(\mathrm{D}_{1}+\mathrm{D}_{2}\right)$, sua associação com abundante magmatismo cálcio-alcalino metaluminoso, bem como o aumento de temperatura para sul, parecem indicar que esta etapa metamórfica pode estar associada ao espessamento e intensa fusão crustal alcançados ao final da etapa colisional.

\section{MAGMATISMO PÓS-COLISIONAL}

Leucogranitos

Tipo-I Ocorrem como diversos batólitos e stocks alongados segundo a direção NE/SW, no Domínio Alóctone
Superior e no setor sul dos domínios alóctones Médio e Inferior. Os corpos mais expressivos já mapeados são: Serra do Ipiranga ou Vassouras (Heilbron et al 1992, Heilbron 1993, Machado 1986), próximo a Barra do Piraí, Getulândia e Fortaleza (Almeida et al. 1993), próximo a Fortaleza, Araras (Machado \& Demange 1992), próximo a Japeri, Pedra Branca (Wiedemann et al. 1990, Junho 1992 e Porto 1993), no Rio de Janeiro (Fig. 8).

O corpo da Serra do Ipiranga, localizado ao sul da cidade de Barra do Piraí, possui fraca foliação subparalela aos contatos com as rochas encaixantes, materializada pela orientação de palhetas de biotita. A falta de deformação intracristalina leva a crer que esta orientação preferencial de minerais tenha sido originada a partir de fluxo magmático, ao final da deformação $D_{3}$. Relações texturais semelhantes são encontradas nos corpos Getulândia e Fortaleza, a sul de Barra Mansa, e Suruí, na baixada fluminense.

Em termos composicionais, os corpos Serra do Ipiranga, Getulândia e Fortaleza são muito homogéneos, variando de monzo a sienogranitos, com biotita como mineral máfico. Os dados litogeoquímicos apontam para composição álcalicálcica, fracamente peraluminosa (índice de Shand entre $1 \mathrm{e}$ $1,1)$. Seus padrões de ETR normalizados por condrito são enriquecidos em ETR leves, com anomalia negativa de Európio. Com base nestes dados foram classificados como granitóides Tipo I muito diferenciados.

Os dados geoquímicos do Granito Pedra Branca permitem classificá-lo como calcialcalino, metaluminoso, semelhante a granitóides tipo-I Caledonianos (Porto Júnior 1993). Neste plúton, a ocorrência de rochas máficas e intermediárias associadas, além de dados texturais e geoquímicos, levou alguns autores a proporem processos de mistura de magmas (Wiedeman et al. 1990). Entretanto, Porto Júnior (1993), com base em dados de campo, petrográficos e geoquímicos detalhados, advoga que as rochas tonalíticas seriam mais antigas e não cogenéticas com o magma granítico, ocorrendo como septos ou roof pendants no interior do batólito granítico. Este autor posiciona o Granito Pedra Branca como tardi-tectônico, admitindo que sua foliação nos bordos é resultante da combinação de fluxo magmático com o campo de esforços da deformação.

Leucogranitos Tipo-S Ocorrem na forma de sills, lentes métricas e pequenos stocks, de granulação média a fina, com foliação fraca, e lentes ou enclaves de rochas supracrustais. São intrusivos nos metassedimentos do Ciclo Deposicional Andrelândia e afloram no setor norte do Domínio Tectônico Inferior. Suas relações de contato com estes metassedimentos são gradacionais e difusas. Esta observação, associada à ocorrência de enclaves de rochas supracrustais refratárias, sugere sua origem a partir da fusão parcial deste conjunto metassedimentar. Os corpos mais expressivos ocorrem no extremo NW da seção e nas folhas Liberdade e Arantina adjacentes, tendo sido abordados em detalhe por Junho et al. (1989). Ocorrem tanto na forma de corpos alongados subparalelos aos planos axiais de megadobras $\mathrm{D}_{3}$, como na forma de lentes paralelas à foliação principal $\mathrm{S}_{2}$ (Junho et al. 1989, Silva 1990).

O Período Pós-tectônico (503-492 Ma) GRANITÓIDES PÓS-TECTÔNICOS $\left(\delta_{5}\right)$ Biotita granitos, com texturas equigranulares a porfiríticas, afloram como stocks, sills ou diques. São corpos isotrópicos e possuem contatos bruscos e xenólitos das encaixantes. Enclaves microgranu- 
lares de rochas gabróicas a dioríticas são frequentes. No segmento da FR investigado, afloram somente no setor sul do DI, na Serra do Mar e região costeira do Estado do Rio de Janeiro. Estes granitos possuem inúmeras denominações locais: Granito Favela (Pires et al 1982); Andorinha (Penha et al. 1980); Nova Friburgo e Sana (Grossi Sad 1980); Teresópolis (Junho 1982); Caju (Ferrari et al. 1982), dentre outras. Machado et al. (subm.) obtiveram idade U/Pb de $492+/-15$ Ma para titanita com baixo teor em U do corpo de Mangaratiba.

Dados litogeoquímicos de Junho (1992) indicam que os corpos de Nova Friburgo, Teresópolis, Frades, Andorinha e Sana possuem composição calcioalcalina a álcali-cálcica, metaluminosa, com teores de $\mathrm{K}_{2} \mathrm{O}$ maiores que $5 \%$. Petrograficamente, variam de hornblenda-biotita granodioritos, biotita granitos (mais abundante) até muscovita-biotita leucogranitos. Esta autora sugere processos de fusão parcial de material basáltico na fácies anfibolito para originar estes magmas, com características tectônicas transicionais entre regimes distensivos e compressivos.

As relações estruturais descritas para todos estes corpos indicam emplacement totalmente pós-tectônico, com relação às fases de deformação compressivas $D_{1}+D_{2}$ e $D_{3}$, da Orogênese Brasiliana. Desta forma, este magmatismo não parece estar relacionado ao período de tempo para a implantação de um arco magmático convencional, pré a sin-tectônico, uma vez que estão temporalmente relacionados ao período póstectônico da orogênese. Mecanismos alternativos, tais como processos de delaminação e underplating, como consequência da extensão litosférica, após o espessamento crustal em regimes de colisão continental, têm sido propostos para explicar a transição para regimes extensionais e magmatismo granitóide do tipo-A e/ou I, como sugerido por Black \& Liegeois (1993) para o Panafricano.

Diques restritos de granito rosa e allanita granito (Penha et al. 1980, Pires et al. 1982, Junho 1992, Heilbron et al. 1993b) cortam o biotita granito acima descrito e, junto com pegmatitos discordantes, representam o final da atividade magmática relacionada à Orogênese Brasiliana, no segmento da FR investigado.

CONSIDERAÇÕES FINAIS A integração dos resultados do mapeamento geológico detalhado com dados analíticos geoquímicos e geocronológicos obtidos neste segmento da Faixa Ribeira, permitem apontar, de forma sintética, suas principais características tectônicas:

- Apesar da Faixa Ribeira representar uma entidade geotectônica formada durante o Neoproterozóico quando da Orogênese Brasiliana, em todos os domínios tectônicos alóctones é alta a proporção de rochas do embasamento (pré-1.8 Ga) siálico reciclado. Os dados geológicos obtidos indicam que as rochas pré-brasilianas ocorrem tanto como embasamento subjacente à cobertura meta-vulcanossedimentar, como em fatias de empurrão, sobre esta cobertura. Associações litológicas do tipo granito-greenstone, características de Terrenos de Baixo Grau; associações de ortognaisse-migmatito-granulito, representantes de Terrenos de Alto Grau, cuja evolução remonta ao Arqueano; e granitóides intrusivos transamazônicos são testemunhos de uma complexa história tectônica Pré-1,8 Ga, que ainda pode ser reconhecida no interior da faixa.

- No Domínio Autóctone e nos domínio alóctones Inferior e Médio, a cobertura, com idade Pós-1,8 Ga, é representada por sequências metassedimentares depositadas sobre embasa- mento siálico. Sua ambientação tectônica (Ribeiro et al 1990, Paciullo et al. 1993, Heilbron 1993,1995) varia de bacias tipo rift (Ciclos Deposicionais Lenheiro e Tiradentes) a bacias do tipo sinéclise ou margem continental do tipo Atlântico (Ciclos Deposicionais Carandaí e Andrelândia). A ampla e regular distribuição das litofácies do Ciclo Deposicional Andrelândia e seus correlates, bem como sua extensa distribuição areal, indicam uma bacia com proporções continentais, de relativa estabilidade tectônica (Paciullo et al 1993). Diversos pulsos de magmatismo básico, com tendência alcalina a mais comumente toleítica, associados a falhamento de blocos, indicam que períodos extensionais perturbaram momentaneamente esta estabilidade tectônica (Paciullo 1992).

- O Grupo Paraíba do Sul, com posicionamento temporal ainda incerto (Heilbron 1993), representa a cobertura no Domínio Alóctone Superior. Possui litofácies características de plataforma carbonática que poderia representar, em princípio, uma bacia de margem continental passiva (Heilbron 1993), uma sinéclise intracontinental ou, ainda, uma bacia retro-arco (Sad \& Dutra 1988). Comparado com as sequências supracrustais dos outros domínios tectônicos, possui uma grande proporção de intercalações carbonáticas. Seu provável embasamento, a Suíte Quirino, é composta por ortognaisses de composição mais ácida, contrastando com as rochas do embasamento dos demais domínios tectônicos. Neste sentido, as diferenças de constituição litológica, tanto do embasamento como da cobertura, entre este domínio tectônico e os demais, poderiam indicar maior aloctonia.

- Os dados estruturais coligidos indicam que a Deformação Principal da Orogênese Brasiliana $\left(D_{1}+D_{2}\right)$ possui inicialmente vergência para o Cráton do São Francisco, com diversas escamas de empurrão movimentadas de SSE para NNW, seguida por uma etapa com importante componente direcional dextral (Fig. 9). Desta forma, a Deformação Principal no segmento central da FR possui uma movimentação geral oblíqua (Heilbron et al 1994). Os diferentes domínios tectônicos mostram variações no estilo estrutural, fruto da deformação em diversos níveis crustais justapostos ao final da deformação. A área que engloba o Domínio Alóctone Inferior e a parte interna do Domínio Autóctone constitui a zona de foreland, na concepção de Hatcher \& Hooper (1992), tipificada por um thrust-fold belt adjacente à área cratônica. Em contraste, nos domínios alóctones Médio e Superior, onde é alta a proporção de rochas do embasamento alóctone (crystalline thrust sheets, na classificação dos autores acima citados), os cavalgamentos sobressaem-se às estruturas dobradas, originando em mapa e perfil um estilo mais amendoado. Algumas escamas de cavalgamento no Domínio Alóctone Médio podem ser classificadas como duplexes crustais. A ocorrência de granulitos, mais competentes, preferencialmente nestes duplexes, sugere que descontinuidades preexistentes no embasamento podem ter controlado e resolvido parte da convergência brasiliana.

- O zoneamento metamórfico registrado na etapa metamórfica $\mathrm{M}_{1}$, concomitante com a tectônica de empurrões $\left(\mathrm{D}_{1}+\mathrm{D}_{2}\right)$, além de ser inverso, ilustra claramente uma polaridade em direção à área cratônica. Assim, as zonas de mais alta temperatura se superpõem às de mais baixa temperatura, e ocorrem progressivamente nas porções mais internas da faixa. A diminuição das condições de pressão ao final da etapa $M_{1}$ é sugestiva para o espessamento crustal resultante do empilhamento das escamas tectônicas, sugerindo um caminho metamórfico do tipo ITD. A etapa $\mathrm{M}_{1}$, relacionada à Deformação 


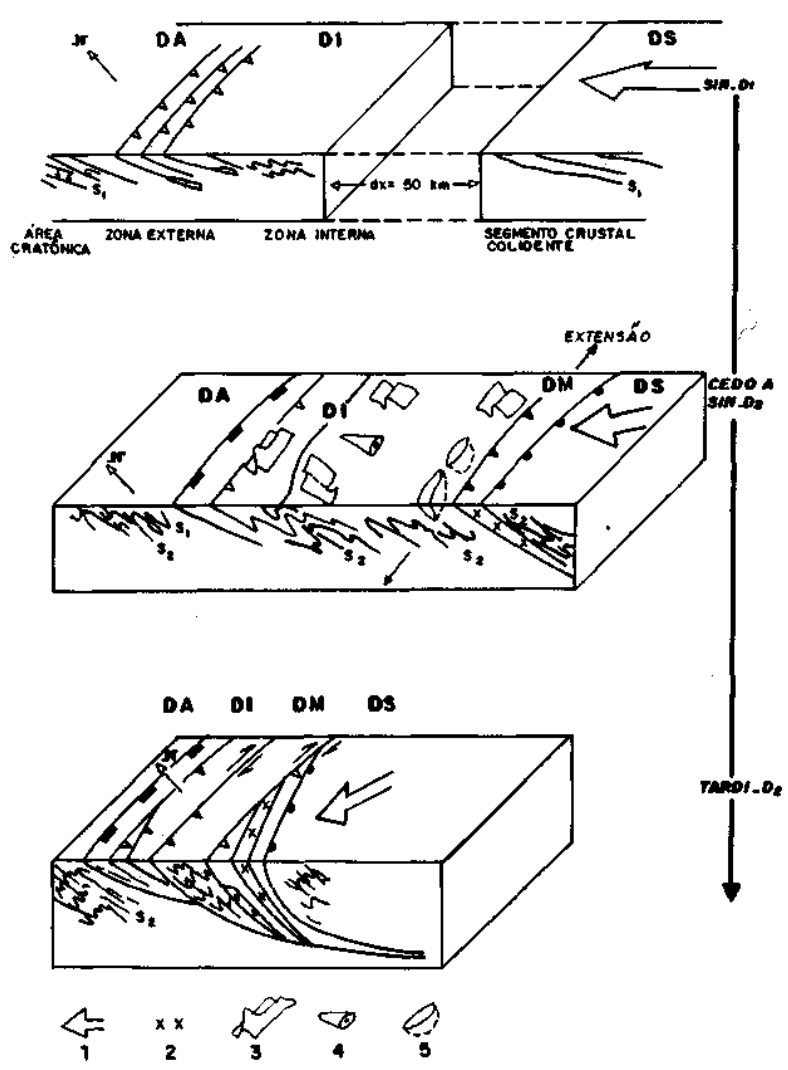

Figura 9 - Quadro esquemático ilustrando a evolução da Deformação Principal $D_{1}+D_{2}$ no segmento central da Faixa Ribeira. $O$ modelo, visualizado com base na análise dos principas indicadores cinemáticos relativos à lineação mineral, propõe uma fase inicial de encurtamento frontal, seguido por uma fase de colisão oblíqua com componente dextral. Abreviatura dos domínios tectônicos é a mesma utilizada em todas as figuras anteriores. Simbologia: 1- A variação na direção do transporte tectônico principal é indicada por setas. 2- Incorporação de rochas do embasamento, 3- Dobras em bainha, 4-Dobrastubulares, 5-Boudinage.

Figure 9 - Evolution of the Main Deformation (D1 + D2) at the central segment of the Ribeira belt, based on the distribution of mineral lineations and kinematic indicators. The Main phase iniciated with a frontal shortening phase followed by a dextral oblique shortening phase. Legend: 1 - Tectonic vergence; 2- tectonic slices with basement rocks; 3- Sheath folds; 4- Tubular folds; 5- Boudinage

Principal $\left(\mathrm{D}_{1}+\mathrm{D}_{2}\right)$ caracteriza o Período Sin-colisional da Orogênese Brasiliana, no segmento da FR investigado, desenvolvido entre 590 e $563 \mathrm{Ma}$

- Dobras e zonas de cisalhamento empinadas, geradas na fase de Deformação $\mathrm{D}_{3}$, perturbam a compartimentação tectônica previamente estabelecida, indicando que a convergência pros-

\section{REFERÊNCIAS}

ALMEIDA, F. F. M. 1969. Diferenciação tectônica da Plataforma Brasileira. In: CONGRESSO BRASILEIRO DE GEOLOGIA, 23, Salvador, 1969. Anais... Salvador, SBG, 1969, p. 29-46.

ALMEIDA, F. F. M. 1977.0 Cráton do São Francisco. Revista Brasileira de Geociências, São Paulo, 7(4):349-364.

ALMEIDA, F. F. M; AMARAL, G.; CORDANI, U. \& KAWASHITA, K. 1973. The Precambrian Evolution of South American Cratonic Margin South of Amazon River. In: The Oceans Basins andMargins (Nairn \& Stelli, Eds.), 1:411-446. Plenum, NY. seguiu após a etapa colisional principal. Dentre as principais estruturas regionais geradas na deformação $\mathrm{D}_{3}$ destacam-se a Megassinforma do Rio Paraíba do Sul, aMegantiformado Rio de Janeiro, e a Zona de Cisalhamento do Paraíba do Sul. O estilo estrutural, a relação com o metamorfismo $\mathrm{M}_{2}$ e a orientação dos elementos estruturais indicam que a deformação $\mathrm{D}_{3}$ representa a continuidade da convergência brasiliana, em nível estrutural mais raso, caracterizando o período TardiColisional, com idades entre 535-520 Ma

- O magmatismo do período compressivo da FR, neste segmento, é representado por granitóides calcialcalinos a alcalicálcicos, do tipo I, e também por plútons do tipo $\mathrm{S}$, sin a tardi-cinemáticos em relação às fases de deformação (Figs. 5 e 8). Dados litogeoquímicos de diversos autores sugerem que ortognaisses semelhantes aos encontrados no embasamento da Faixa Ribeira poderiam representar, em parte, a fonte crustal dos granitóides tipo I. Enclaves e rochas básicas associadas a estes granitóides do tipo I podem ainda indicar contribuição mantélica. A distribuição das rochas granitóides também é claramente assimétrica, sendo o magmatismo brasiliano progressivamente mais abundante para a porção interna da faixa, do setor norte do Domínio Médio para o sul. Esta abundância relativa, acompanhada do progressivo retrabalhamento crustal, na região estudada, reforça a sugestão de um espessamento crustal na direção SE.

- dobras e zonas de cisalhamento íngremes, com orientação transversal à faixa, caracterizam a Deformação $\mathrm{D}_{4}$, com estilo estrutural dúctil/rúptil, gerada em um provável regime transtensional.

- granitóides calcialcalinos a álcali-cálcicos, totalmente póstectônicos, ocorrem como pequenos plútons circunscritos, sills e diques, parecendo estar relacionados à transição para o regime distensional fanerozóico, resultante do resfriamento após a convergência brasiliana. Os dados $\mathrm{U} / \mathrm{Pb}$ indicam atividade entre 503 e 492 Ma.

Agradecimentos Os autores agradecem ao colegas do Departamento de Geologia Regional e Geotectônica da Faculdade de Geologia da UERJ, Júlio C.H. Almeida, Miguel Tupinambá e Beatriz Duarte, pela dedicação, ao longo de dez anos de trabalho, ao mapeamento geológico detalhado no segmento central da Faixa Ribeira, que sustentam esta proposta de integração regional. As sugestões finais do texto foram realizadas por António Thomaz Filho e por Mário Campos Neto. A leitura crítica e sugestões construtivas da tese de livre docência, defendida pela autora, na UERJ em 1995, base deste trabalho, foram realizadas por António Thomaz Filho, Benjamin Bley Brito Neves, Rudolph Trouw, Joel Valença e Pedro Zalán. A autora agradece ainda os recursos para as pesquisa, fornecidos pelo CNPq, Faperj e Padct/Finep, ao longo do trabalho de pesquisa.

ALMEIDA, F. F. M.; HASUI, Y. \& BRITO NEVES B. B. 1976. The Upper Precambrian of South America. Boi. IG-USP, São Paulo 7:45-80.

ALMEIDA, J. C. H.; SILVA, L. G. E. \& VALLADARES, C. S. 1993. O Grupo Paraíba do Sul e rochas granitóides na região de Bananal (SP) e Rio Claro (RJ): uma proposta de formalização litoestratigráfica. In: SIMPÓSIO DE GEOLOGIA DO Sudeste, 3, Rio de Janeiro, 1993. Atas... Rio de Janeiro, SBG., p: 1161-167.

ALMEIDA, J. C. H. (1994) Caracterização geométrica do rejeito da Zona de Cisalhamento de Três Corações, Sul de Minas Gerais. In: Congresso brasileiro de geologia, 38, Camboriú, Boi. Resumos Expandido, SBG, Camburiú, SC 
BARBOSA, A.L.M. 1966. Síntese da Evolução Geológica da América do Sul. Boi. do Instituto de Geociências da Escola de Minas de Ouro Preto, 1:91-111.

BARNICOAT, A. C. \&TRELOAR, P. J. 1989. Himalayan metamorphism-an introduction. J. Metam. Geol., 7(1):3-8.

BITTAR, S. M. 1990. Mapa geológico estrutural da folha Caxambu de parte Sul da folha Luminárias, MG. In: congresso brasileiro de Geologia, 36, Natal, 1990. Anais... Natal, SBG. V.6: 2798-2807.

BLACK, R. \& LTEGEOIS, J. P. (1993) Cratons, mobile belts, alkaline rocks and continental lithospheric mantle: the Pan-African testimony. J. Geol. Soe. London, 150:89-98.

BRITO NEVES, B. B. \& CORDANI, U. G. 1991. Tectonic Evolution of South America during the Late Proterozoic. Precambrian Research, 53: 23-40

BRUNEL, M. \& KIENAST, J. R. 1986. Etude pétro-structurale dês chevauchements ductiles himalayens sur Ia traversale de 1'Everest Makalu (Nepal Oriental). Can. Journ. Earth Scienc., 23: 1117- 1137.

CAMPANHA, G.A.C.\& FERRARI, A.L. 1984. Lineamento Além Paraíba: um exemplo de zona de cisalhamento. In: congresso brasileiro de Geologia, 38, Rio de Janeiro, 1984, Anais... Rio de Janeiro, RJ ,SBG. v. 12: 5425-5432.

CAMPOS NETO, M. C. 1992. A porção ocidental da Faixa Alto Rio GrandeEnsaio de Evolução Tectônica. Tese de Doutoramento, IG-USP. 210p (inédito).

CAMPOS NETO, M. C. \& FIGUEIREDO, M. 1992. A Orogênese Rio Doce. In: congresso brasileiro de Geologia, 37, São Paulo, Boi. de Resumos Expandidos... São Paulo, SBG. V'.1: 276-277.

CAMPOS NETO, M.C. \& FIGUEIREDO, M.C.H. 1995. The Rio Doce Orogeny, Southeastern Brazil. Jour. South Amer. Earth Sei., 8 (2): 143-162

CASTRO, H. O.; QUEIROZ, M. A.; BARBOSA, A. L. \& SAD, J. H. G. 1984. Geologia das folhas Rio Preto, Valença, Barra do Piraí e Vassouras. In: congresso brasileiro de Geologia, 38, Rio de Janeiro. Anais... Rio de Janeiro, SBG. p. 2346-2354.

CHRISPIM, S. e TUPINAMBÁ, M.A. (1989) Observações sobre o caráter transpressivo da deformação entre as zonas de cisalhamento do Paraíba do Sul (RJ) e Guaçuí (ES). IN: Simpósio de Geologia do Sudeste, I, Anais...., Rio de Janeiro, SBG/RJ, pp. 120-121.

COBBOLD, P. Q. \& QUINQUIS, H. 1980. Development of sheath folds in shear regimes. J. Struct. Geol., 2:119-126.

CORDANI, U. G.; DELHAL, L. \& LEDENT, O. 1973. Orogéneses Superposées dans lê Precambrien du Brésil Sud-Oriental (États de Rio de Janeiro et de Minas Gerais). Rev. Brás. Geoc., 3(1): 1-22.

CORDANI, U. G.; AMARAL, G. C. \& KAWASHITA, K. 1973. The Precambrian Evolution of South America. Geol. Rund., 62(2): 309-317.

CORRÊA NETO, A. V.; DAYAN, H.; VALENÇA, J.G. \& RAPHAEL CABRAL, A. 1993. Geologia e Estrutura da Zona de Cisalhamento do Rio Paraíba do Sul e Adjacências, no trecho entre Três Rios e Sapucaia (RJ). In: Simpósio de Geologia do Sudeste, III, Rio de Janeiro, 1993. Atas... Rio de Janeiro, SBG., p: 194-200.

DAYAN, H. \& KELLER, J.V.A. 1989. A Zona de Cisalhamento do Rio Paraíba do Sul nas vizinhanças de Três Rios (RJ): Uma análise da deformação dada por algumas feições estruturais. Rev. Brás. Geoc., 19(4):494-506.

DIOS, F.R.B.; ALMEIDA, J.C.H.; CRUZ, E.L.C. (1993) Seção geológica entre Mangaratiba e Rio Claro, RJ. In: Simpósio de Geologia do Sudeste, 3, Rio de Janeiro, 1993, Anais... SBG, pp. 161-167.

DELHAL et al. 1969. Ages $\mathrm{Pb} / \mathrm{U} ; \mathrm{Sr} / \mathrm{Rb}$ et $\mathrm{Ar} / \mathrm{K}$ de Formations Métamorphiques et Granitique du Sud-Est du Brésil (Etats de Rio de Janeiro e Minas Gerais). An. Soe .Geol. Belg., 92: 271-283.

DUARTE, B. P.; NOGUEIRA, J. R.; HEILBRON, M. \& FIGUEIREDO, M. 1994. Geologia da Região de Juiz de Fora e Matias Barbosa (MG). In: congresso brasileiro de Geologia, 38, Boi. de Resumos Expandidos,... Camboriú, SC, SBG, V.2: 88-90.

EBERT, H. 1968. Ocorrência da fácies granulítica no sul de Minas Gerais e em áreas adjacentes, em dependência de sua estrutura orogênica: Hipótese sobre sua origem. An. Acad. Brás. Ciênc., 40(supl):215-229. Rio de Janeiro.

EBERT, H. 1984 (in memorian). Os Paraibides entre São João dei Rei (Minas Gerais) e Itapira (São Paulo) e a bifurcação entre Araxaídes e Paraibides. Publ. Esp., SBG-SP, 12: 1-103.

EBERT, H. D.; HASUI, Y.; COSTA, J.B.S. 1991.0 caráter transpressivo do Cinturão de Cisalhamento Rio Paraíba do Sul. IN: III Simpósio Nacional de estudos tectônicos. B0L..,IGCE/UNESP-SBG/SP, Rio Claro-SP: 139-141.

FERRARI, A.L.; BRENNER, T.L.; DALCOMO, M.T. \& NUNES, H.R.C.

1982.0 Pré-Cambriano das Folhas Itaboraí, Maricá, Saquarema e Baía da Guanabara. In: congresso brasileiro de Geologia, 32, Salvador, 1982. Anais... Salvador, SBG. v.1, p. 103-113.
FONSECA, A. C. 1994. Esboço geocronológico da região de Cabo Frio, estado do Rio de Janeiro. Tese de Doutoramento, IG-USP, $186 \mathrm{p}$.

FONSECA, M. J. G.; SILVA, Z. C. G.; CAMPOS, D. A. \& TOSATO, P. 1979. Mapa e texto explicativo das folhas Rio de Janeiro, Vitória e Iguape, na escala de 1:1.000.000 (SF23, SF24, e SG230). DNPM. Brasília.

GONÇALVES.M . L. 1987. Geologia da área de Santana do Garambéu, $M G$. Dissertação de mestrado IG-UFRJ 113p (inédito).

GONÇALVES, M. L. 1986. A geologia da área de Santana do Garambéu, MG. In: congresso brasileiro de Geologia, 35, Goiânia, 1986. Anais... Goiânia SBG. V.2: 1999-1109.

HARLEY, S. L. 1989. The origin of granulites. A metamoorphic perspective. Geol. Mag., 126:215-240

HASUI, Y. 1982. The Mantiqueira Province: Archean Structure and Proterozoic Evolution. In: Int. Symp. Archean and Early Proterozoic Geological Evolution and Metallogenesis, Salvador, BA.

HASUI, Y.; CARNEIRO, C, D, R, \& COIMBRA, A. M. 1975. The Ribeira Fold Belt. Rev.Brás. Geoc., 5(4): 257-266.

HASUI, Y. \& OLIVEIRA, M. A .F. 1984. A Província Mantiqueira: Setor Central. In: Almeida \& Hasui (edit.) 1984, O Precambriano do Brasil, Edgard Blucher, 344 p.

HATCHER Jr., R. D. \& HOOPER, R. J. 1992. Evolution of crystalline thrust sheets in the internai parts of mountain chains. In: McClay, K. R. (ed.), Thrust Tectonics, Part Three: Thrust Geometries and Thrust Systems, Chapman \& Hall, London, pp. 217-233.

HEILBRON, M. 1985. O metamorfismo da área entre Itutinga e Madre de Deus de Minas - MG. Simp. Geol. Minas Gerais, 3, Belo Horizonte, MG, Anais..., SBG, Núcleo de Minas Gerais, Belo Horizonte, MG, Boi 5:219-234.

HEILBRON, M. 1990. O limite entre as faixas de dobramento Alto Rio Grande e Ribeira na seção geotransversal Bom Jardim de Minas (MG)Barra do Piraí (RJ). In: congresso brasileiro de Geologia., 36, Natal, Anais...Natal, RN, SBG, v.6:2813-2826.

HEILBRON, M. 1993. Evolução tectono-metamórfica da Seção Bom Jardim de Minas (MG) -Barra do Piraí (RJ). Setor Central da Faixa Ribeira. Tese de Doutorado, Instituto de Geociências - Universidade de São Paulo, 268 p.(inédito).

HEILBRON, M. 1995.0 Segmento Central da Faixa Ribeira: Compartimentação Tectônica e Ensaio Evolutivo. Tese de Livre Docência, Universidade do Estado do Rio de Janeiro, 115p (inédito).

HEILBRON, M.; GONÇALVES, M.L.; TEIXEIRA, W. TROUW, R. A. J.; KAWASHITA, K. \& PADILHA, A. 1989. Geocronologia da área entre Lavras, São João dei Rei, Lima Duarte e Caxambu. An. Acad. Brás. C/ê/jc.,61(2):177-199.

HEILBRON, M.; PIRES, F. R. M. \& BESSA, M. 1993b. Litoestratigrafia, evolução tectono-metamórfica e magmatismo do setor sudeste do Município Rio de Janeiro. IN: Simp. Geol. Sudeste, 3, Rio de Janeiro, 1993. Atas... Rio de Janeiro, SBG., p: 174-179.

HEILBRON, M.; ROCHA, A.D.; SILVA, L. G. E.; NOGUEIRA, J. R.; TROUW, R.; POLÓNIA, J. A. L. 1994. Compartimentação tectônica na seção Conceição do Ibitipoca (MG)- Valença (RJ), segmento central da Faixa Ribeira. In: congresso brasileiro de Geologia, 38, Boi. de Resumos Expandidos ...Camboriú, SC, SBG, V.2: 55-56.

HEILBRON, M.; SANTOS, R. O.; VALLADARES, C. S. \& VALERIANO, C. M. 1992. Geologia e lito-geoquímica do leucogranito Serra do Ipiranga In: congresso brasileiro de Geologia, 37, São Paulo, Boi. de Resumos Expandidos... São Paulo, SBG., p.375-376.

HEILBRON, M.; VALERIANO, C. M.; ALMEIDA, J. C. H. \& TUPINAMBÁ, M. 1991. A Megassinforma do Paraíba do Sul e sua implicação na compartimentação tectônica do setor central da Faixa Ribeira. In: Simp. Geol. Sudeste, 2, São Paulo, Atas..., São Paulo, SBG, p. 519-527.

HEILBRON, M.; VALERIANO, C. M.; ALMEIDA, J. C. H., TUPINAMBÁ, M. \& VALLADARES, C. S., SILVA, L. G. E.; NA VA, D.B. \& DIOS, F.B. 1993a. Compartimentação tectônica e evolução geológica do segmento central da Faixa Ribeira, ao sul do Cráton do São Francisco. IN: Simpósio sobre o Cráton do São Francisco, II, Salvador, Anais..., Salvador, Bahia, SBG,p: 263-265.

HEILBRON, M.; VALERIANO, C.M.; ALMEIDA, J.C.H.; VALLADARES, C.S.; TUPINAMBÁ, M. 1994. Segmento central da Faixa Ribeira, exemplo de colisão continental oblíqua no evento termo-tectônico Brasiliano. In: congresso brasileiro de Geologia, 38, Camboriú, Boi. Resumos Expandidos..., SBG, Camboriú, SC, Vol. 1 pp. 263-265.

HEILBRON, M.; ROCHA, A.D.; SILVA, L.G.E.; NOGUEIRA, J.R.; TROUW, R.A.J.; POLÓNIA, J.A.L. (1994) Compartimentação tectônica da seção Conceição do Ibitipoca-Valença (RJ), segmento central da Faixa Ribeira. In: congresso brasileiro de Geologia, 38, Boi. Resumos Expandidos..., Camburiú, SBG, vol. 2, pp. 55-56. 
HELMBOLD, R; VALENÇA, J.G. \& LEONARDOS Jr., O.H. 1965. Mapa Geológico do Estado da Guanabara, escala 1 :50.000. Rio de Janeiro, DNPM/MME

JUNHO, M. C. B. 1990. Contribuição àpetrologia dos maciços Graníticos de Pedra Branca. Nova Friburgo e Frades, RJ. Tese de Doutoramento, IG-UFRJ (inédito), 172p.

JUNHO, M. C. B. 1992. Granitóides brasilianos na região central do estado do Rio de Janeiro. In: congresso brasileiro de Geologia, 37, São Paulo, Boi. Resumos Expandidos... São Paulo, SBG., p.398-400.

LAMEGO, A.R. 1936. O maciço de Itatiaia e e regiões circundantes,. Boi. SGM/DNPM88, 1-93

MACHADO FILHO, L.; RIBEIRO, M.; GONZALEZ, S. R.; SCHENINI, C. A.; SANTOS NETO, A. DOS; PALMEIRA, R. C.; PIRES, J. L.; TEIXEIRA, W.; CASTRO, H. E. F. 1983. Geologia das folhas Rio de Janeiro (SF 23/24) escala 1:1.000.000, mapa e texto explicativo. RADAM Brasil-MME, Rio de Janeiro, 780p.

MACHADO, R. 1983. Considerações sobre a estrutura tectônica divergente da porção ocidental do estado do Rio de Janeiro. In: Simp. Reg. Geol.,4, São Paulo, Anais... SBG/SPp. 132-145.

MACHADO, R. 1984. Evolução geológica, análise estrutural e metamórfica da região de Vassouras e Paracambi, Rio de Janeiro. Tese de Doutoramento IG-USP, 196p. (inédito).

MACHADO, R. \& DEMANGE, M. 1992. Granitogênese brasiliana no estado do Rio de Janeiro: caracterização geoquímica, modelo geotectônico e considerações geológicas sobre o embasamento e a cobertura do Cinturão Ribeira na região. In: congresso brasileiro de Geologia, 37, São Paulo, Boi. de Resumos Expandidos... São Paulo, SBG., V. 1:379-380.

MACHADO, R \& ENDO.I. 1993. Estruturas transcorrentes na borda sul do Cráton do São Francisco. In: Simpósio sobre o Cráton do São Francisco, II, Salvador, Anais..., Salvador, Bahia, SBG, p:269-271.

MOHAN, A.; WINDLEY, B. F. \& SEARLE, M. P. 1989. Geothermobarometry and development of inverted metamorphism in the Darjeeling-Sikkim region of eastern Himalaya. J. Metam. Geoi, 7:95-110.

NOCE, C.M. 1987. Uma interpretação da clivagem SI e da primeira fase de deformação em cinturões dobrados de baixo grau - o caso do Grupo São João dei Rei. In: Simp"sio de Geologia de Minas Gerais, IV. Anais... SBG, Núcleo de Minas Gerais, boi. 7, pp. 226-236.

NOGUEIRA, J. \& TROUW, R. 1993. Mapeamento geológico, escala 1: 50.000 , estruturas e metamorfismo de uma região a sudoeste de Juiz de Fora, MG. In: Simpósio de Geologia do Sudeste, III, Atas..., SBG, p: 180-186.

NUMMER, A. R. 1992. Análise Estrutural e Estratigráfica do Grupo Andrelândia na região de Santa Rita do Ibitipoca-Lima Duarte, sul de Minas Gerais. Dissertação de Mestrado-IG/UFRJ (inédito). 191p.

OLIVEIRA, M. A. F. 1981. Granulitos da Faixa Paraíba do Sul: caracteres geoquímicos dos piroxênios e valores geotermométricos. Rev. Brás. Geoc., 11(4):222-226.

PACIULLO, F. V. P. 1992. Orto-anfibolitos no Ciclo Deposicional Andrelândia- Assinatura química e ambiente tectônico. In: Congresso Brasileiro de Geologia, 37, São Paulo, Boi. de Resumos Expandidos..., São Paulo, SBG, V. 2: 28-30,

PACIULLO, F. V. P., RIBEIRO, A. \& ANDREIS, R. 1993. Reconstrução de uma bacia fragmentada: o caso do Ciclo Deposicional Andrelândia. In: Simpósio sobre o Cráton do São Francisco, II, Salvador, Anais..., Salvador, SBG, p:224- 226.

PASSCHIER, C. W. \& SIMPSON, C. 1986 Porphyroclast systems as kinematic indicators. J. Struct. Geol. 8(8):831-843.

PENHA, H.M.; FERRARI, A.L.; RIBEIRO, A.; AMADOR, E.S.; PACIULLO,F.V.P.; JUNHO, M.C.B. \& BRENNER. T.L. 1980. A geologia da folha Petrópolis. In: congresso brasileiro de Geologia, 31, Camboriú, 1980, Anais... Camboriú, SBG, v.5:2965-2974.

PIRES, F.R.M.; VALENÇA, J.G. \& RIBEIRO, A. 1982. Multistage generation of granite in Rio de Janeiro, Brazil. Rio de Janeiro, An. Acad. Brás. Ciênc., 54 (3): 563-574

PIRES, F.R.M.; HEILBRON, M. \& da SILVA, P.C.F. 1986. Polimetamorfismo dos gnaisses do Rio de Janeiro, RJ. In: congresso brasileiro de Geologia, 34, Goiânia, 1986. Anais... Goiânia, SBG. v.4, p. 1451-1463.

PORTO JÚNIOR, R. 1993. Petrologia das rochas graníticas das Serras da Pedra Branca e Misericórdia, município do Rio De Janeiro. Dissertação de Mestrado, DGEL/UFRJ, 222p (inédito).

REIS, A.P.; CASTRO, O. H.; PUGET, A.J.F.; BARBOSA, L.; RIBEIRO, A.C.; PINTO, C.P.; DUTRA, J.E.B.; SAD, J.H.G. \& TULLER, M.P. 1982. Geologia das folhas Três Rios, Paraíba do Sul, Miguel Pereira e Cava. 1982. In: congresso brasileiro de Geologia, 32, Salvador, Anais..., Salvador, SBG, vol. 1, p: 94-102.
RIBEIRO, A. 1992. Diques máficos proterozóicos em São João dei Rei. In: congresso brasileiro de Geologia, 37, São Paulo, Boi. de Resumos Expandidos..., São Paulo, SBG, v. 1:508-509.

RIBEIRO, A.; PACIULLO, F. V. P; ANDREIS R. R.; TROUW, R. A. J. \& HEILBRON, M. 1990. Evolução policíclica proterozóica no sul do Cráton do São Francisco: análise da região de São João dei Rei e Andrelândia, MG. In: congresso brasileiro de Geologia, 36, Natal, Anais..., Natal, SBG, vol. 6, pg. 2605-2614.

ROSIER, G. F. 1965. Pesquisas geológicas na parte oriental do Estado do Rio de Janeiro e na parte vizinha do Estado de Minas Gerais. Boi. Div. Geol Min., DNPM, Rio de Janeiro, 222p.

SAD, J. H.G. \& BARBOSA, L. 1985. A origem dos charnockitos e rochas afins da região do Médio Paraíba do Sul, estado do Rio de Janeiro. Contribuições à geologia e petrologia. Boi. Especial da $S B G$, Núcleo de Minas Gerais, p: 15-28.

SAD, J. H. G. \& DUTRA, C. 1988. Chemical composition of supracrustal rocks from Paraíba do Sul Group, Rio de Janeiro State, Brazil. Geochim. Brasil., 7(2): 143-174.

SILVA, P.C.F. da \& SILVA, R.R. da 1987. Mapeamento geológico-estrutural da Serra da Carioca e adjacências, município do Rio de Janeiro. In: SIMP. GEOL. REGIONAL, 1, Rio de Janeiro, 1987, Anais... Rio de Janeiro, SBG., p. 198-209.

SILVA, L.G.E; NAVA. D.B; HEILBRON.M. \& VALERIANO, C.M. 1991. Geologia de detalhe da Serra da Carioca, cidade do Rio de Janeiro. In: Simp. Geol. Sudeste, 2, São Paulo, Atas..., São Paulo, SBG, p. 161-170.

SILVA, R.R. 1991. E\&tratigrafia, metamorfismo e geologia estrutural do Grupo Andrelândia em Carvalhos, sul de Minas Gerais. Dissetação de Mestrado, IG/UFRJ. (inédito).

TASSINARI, C.C.G. \& CAMPOS NETO, M.C. 1988. Precambrian continental crust evolution of Southeastern São Paulo State, Brazil, based on isotopic evidence. Geochim. Brasil., 2(2):175-183.

TEIXEIRA, W. \& FIGUEIREDO, M. C. H. 1991. An outline of Early Proterozoic crustal evolution in the São Francisco Cráton, Brazil: a review. Precambrian Rés., 53: 1-22

TEIXEIRA, W.; CORDANI, U. G.; KAWASHITA, K.; TAYLOR, P. N. \& VAN SCHMUS, W. R. 1987. Archaean and Early Proterozoic crustal evolution in the southern part of the São Francisco craton. In: Int. Symp. Granites and Associated Mineralizations, Salvador, Extended Abstr... Salvador, SBG, p: 37-40.

TROUW, R. A. J. 1992. Evolução tectônica ao sul do Cráton do São Francisco, baseada em análise metamórfica. In: congresso brasileiro de Geologia, 38, São Paulo, Boi. de Resumos Expandidos... São Paulo, SBG, 1:327-328.

TROUW, R. A. J. \& PANKHURST, R. J. 1993. Idades radiométricas ao sul do Cráton do São Francisco: região da Folha Barbacena, Minas Gerais. In: Simpósio sobre o Cráton do São Francisco, II, Salvador, Anais..., Salvador, SBG,p: 260-263.

TROUW, R. A. J.; RIBEIRO, A. \& PACIULLO, F. V. P. 1986. Contribuição à geologia da folha Barbacena 1:250.000. In: congresso brasileiro de Geologia, 34, Goiânia, Anaw...,Goiânia, SBG, V. 2:972-986.

TROUW. R. A. J.; RIBEIRO, A.; PACIULLO, F. V .P. 1994. A faixa Alto Rio Grande reinterpretada como a zona de interferência entre a Faixa Brasília e Faixa Ribeira. In: congresso brasileiro de Geologia, 38, Camboriú, Boi. de Resumos Expandidos...,Camboriú, SBG, V. 1:234235.

VALERIANO, C. M. 1985. Geologia Estrutural e Estratigrafia do Grupo São João dei Rei, na região de São João dei Rei, MG. Dissertação de Mestrado, IG/UFRJ., 98p. (inédita).

VALERIANO, C.M. \& MAGALHÃES, A.C. 1984. Geologia estrutural da área do Pão de Açúcar e adjacências, Rio de Janeiro, Brasil. Rio de Janeiro. An. Acad. Brás. Ciênc., 56(3): 295-301.

WffiDEMANN, C. M.; VASCONCELOS, A.C.; BATISTA, J. 1990. Mecanismos de mistura magmática no maciço da Pedra Branca, RJ: uma análise através de feldspatos complexos. In: congresso brasileiro de Geologia, 36, Natal, Anais..., Natal, SBG, vol. 3, pg. 1128-1136.

ZIMBRES, E., KAWASHITA, K. \& VAN SCHMUS, W. R. 1990. Evidências de um núcleo transamazônico na região de Cabo Frio, RJ e sua conexão com o Cráton de Angola. In: congresso brasileiro de Geologia, 36, Natal, Anais..., Natal, SBG, v 6, pg. 2735- 2743.

MANUSCRITO N$^{\circ} 864$

Recebido em 31 de agosto de 1996 Revisão dos autores em 30 de novembro de 1996 Revisão aceita em 15 de janeiro de 1997 